Article

\title{
Examining the Business Case and Models for Sustainable Multifunctional Edible Landscaping Enterprises in the Phoenix Metro Area
}

\author{
Christopher Robinson * (1), Scott Cloutier (1) and Hallie Eakin \\ School of Sustainability, Arizona State University, 800 Cady Mall, Tempe, AZ 85281, USA; \\ scott.cloutier@asu.edu (S.C.); Hallie.Eakin@asu.edu (H.E.) \\ * Correspondence: crobins7@asu.edu; Tel.: +1-602-516-6834
}

Received: 7 November 2017; Accepted: 8 December 2017; Published: 12 December 2017

\begin{abstract}
This study assesses whether multifunctional edible landscaping business models provide a sufficient business case at enterprise and city scales to justify widespread implementation. First, semi-structured interviews were conducted with four landscaping entrepreneurs, and the information obtained from the interviews was utilized to carry out a business model comparison with the Business Model Canvas framework. The comparison showed that the landscaping enterprises using multifunctional edible landscaping methods possessed a greater range of value propositions and revenue streams, enhancing their competitive advantage. Second, a GIS landscape analysis of seven Phoenix metro area cities was carried out to identify landscapes that were suited for becoming multifunctional edible landscapes. The GIS analysis identified single family residential, residential recreational open space, municipal parks, and municipal schools as being suitable landscapes, and that the area of these landscapes in the seven cities exceeded 180,000 acres. Third, scenarios were created using interview and GIS data to estimate potential value creation and return on investment of implementing multifunctional edible landscaping in the cities of interest. The scenarios found that the potential value creation of edible landscaping ranged between $\$ 3.9$ and $\$ 66$ billion, and that positive return on investment (ROI) could be achieved in 11 out of 12 scenarios within one to five years. Finally, the paper concludes by discussing potential long-term implications of implementing multifunctional edible urban landscaping, as well as possible future directions for multifunctional landscaping business model development and research.
\end{abstract}

Keywords: multifunctional landscapes; edible landscaping; urban agriculture; urban forestry; sustainable business models; GIS analysis; ROI scenarios

\section{Introduction}

\subsection{Sustainability Challenges of Urban Landscapes}

Critical to addressing urban sustainability issues is the design and use of urban landscapes, which play a significant role in facilitating or hindering the urban activities that take place within their physical space [1]. Urban landscapes also represent a significant ratio of urban resource consumption, as considerable material and human resources are devoted to constructing, utilizing, and maintaining them [2]. Additionally, urban land use and design can directly influence the well-being and happiness of urban residents, affecting both physical and mental conditions [1]. However, while the importance of landscapes is well recognized, the predominant approach for landscape design and use impedes the full realization of landscape potential [3].

Since the advent of industrialization, the predominant landscape management approach in modern western society has been the segregation of land into single purpose landscapes designed to 
maximize one primary function or production unit output [3]. To clarify, we do not use the term "single purpose landscape" to mean that a landscape does not possess multiple purposes or functions, but that a landscape was designed in a manner that prioritizes one primary function over all other functions. This single purpose mindset also frames thinking around urban landscapes, observed by urban zoning and property use codes that designate land parcels for one primary use. This monofunctional framing occurs despite the reality that many urban landscapes are comprised of closely clustered tracts of land hosting many simultaneous and overlapping functions. Since fewer landscape factors and interactions are considered, the single purpose approach is often prone to overlook potential conflicts or synergy between neighboring landscapes, missing opportunities for additional value creation and resource efficiency improvements. There are also several urban sustainability issues that are frequently associated with the single purpose landscape approach in urban areas, such as food insecurity from lack of edible landscapes, urban flooding from poor storm water management functions, vacant or neglected landscapes that lack beneficial functions or support dysfunctions such as criminal activities, and so on. Because of these issues, certain urban landscapes would be better served with a different landscape approach, one that better recognizes functional interactions between and within landscapes, and enables multifunctional landscape design and use [1,4-6].

\subsection{Multifunctional Urban Landscapes}

The contemporary origin of multifunctional landscapes can be traced to holistic shifts in landscape ecology research and the emergence of several alternative natural resource management frameworks (e.g., permaculture, agroecology, agroforestry, etc.) that occurred during the 1970s; however, discussions during the early 2000s on sustainable landscape development resulted in multifunctional landscapes to begin coalescing as a transdisciplinary sub-field [3,5,7-11]. The multifunctional landscape approach integrates cultural knowledge drawn from traditional pre-industrial landscapes designs, featuring close integration of multiple uses and functions, with modern transdisciplinary scientific methods and knowledge for landscape design and use. The approach is also defined by the comprehensive identification of land use functions and demands, analyzing the mutual interactions of land use functions to identify conflicts and synergies, incorporating participative cooperation of landscape stakeholders in selecting land use combinations, and an iterative decision-making process that adapts to uncertainties and emerging knowledge [9]. Using the multifunctional landscape approach in urban landscapes could improve the recognition of different urban landscape functions and their interactions, allowing for superior design integration of existing functions, improved resource efficiency, added value creation from incorporating new functions, as well as providing a framework for grading urban landscape planning and performance [1].

However, since multifunctional landscapes as a sub-field is still developing, most research work in the area done to date has not been related to urban landscapes, and has instead primarily focused on framework and toolset development, disciplinary knowledge integration, and rural landscape projects $[1,3,9,12]$. In addition to a lack of research, most existing models of urban multifunctional landscapes, predominately in the form of urban agriculture or edible landscapes, have not achieved widespread adoption [13]. To clarify, the terms "urban agriculture" and "edible landscapes" can broadly refer to a wide variety of landscape types which produce food for human consumption, including outdoor or indoor farms, orchards, community gardens, home gardens, and so forth. There are many reasons why these models remain marginalized, but the issue that this paper focuses on is the failure of existing models to provide sufficient incentives for key urban landscape stakeholders, specifically landowners and the landscape service industry, to pursue multifunctional landscapes. Better stakeholder understanding of the values provided by multifunctional landscapes would enhance their incentive to adopt them. For clarification, we primarily use the term "values" to refer to economic or financial values (e.g., value for money or economic value added for landscape stakeholders); however, in certain instances, especially when discussing public landscapes or landscapes managed via public-private partnership, "values" is meant in a similar manner to the "Sustainable Value Added" 
approach and can also include non-financial values (e.g., social, public, environmental, etc.) derived from improved or increased landscape functionality [14-18].

Currently, most multifunctional urban landscaping models, such as home gardens, community gardens, urban farms, or urban forestry programs, tend to place the burden of implementation and caretaking on landowners or residents, rather than landscaping enterprises. Furthermore, multifunctional landscapes usually take more effort to build and maintain than single purpose landscapes as they are typically more complex to manage. Additional planning and precision is often needed for successful integration and operation of multiple landscape functions, which consequently necessitates drawing upon a greater variety of knowledge, skills, and tools, as well as investing more time than what is usually required for single function landscapes $[1,13]$. These factors are significant disincentives for urban landowners and residents with non-landscape related professions, as many do not have sufficient money, time, interest, or expertise to devote toward proper landscape care [2]. Many multifunctional models also fail to incorporate the existing landscaping service industry, which relies upon business models that encourage the implementation and maintenance of single purpose landscapes, most of which tend to be ornamental or recreational landscapes. This oversight is significant because of how much influence the landscaping industry has on urban landscape decision-making, as many landowners make their landscaping choices according to the design and service options provided by landscaping service companies [2,19]. The economic impact of the landscaping services industry is also noteworthy, with industry revenues exceeding $\$ 83$ billion ( $\$ 6$ billion profit) and more than 500,000 participating enterprises (of which three-quarters are sole proprietors) employing about 1 million workers, the largest enterprise being Brightview with $\$ 2$ billion in revenue and 22,000 employees as of 2014 [20,21]. For multifunctional urban landscaping to achieve widespread implementation, urban landscaping business models should incentivize both landowners and the landscaping industry to willingly transition from single purpose to multifunctional landscapes. One way to achieve this is through business model innovations that restructure the value chains and decision-making around urban landscapes.

\subsection{Business Model Innovations as Catalysts for Sustainable Transitions}

Recent research has focused on the potential of business model innovations as a solution pathway for addressing various sustainability challenges [22,23]. While sustainability problems can often be linked to unsustainable business practices by private enterprises, the flexible nature of private enterprises (whether for-profit or non-profit) makes them well-suited as change agents to help address sustainability challenges. Private enterprises tend to have resources that enable action and are less constrained by geographic, political, and cultural barriers than other stakeholders [24]. Nevertheless, it must be acknowledged that the profit maximization prerogatives of for-profit private enterprises acting within contemporary market systems have historically led them to carry out unsustainable behaviors in the absence of strong market regulation [25]. To address this systemic issue in markets where establishing strong regulations are difficult or impractical, some have proposed the development and proliferation of non-profit (which are mission rather than profit driven) or so called "hybrid" enterprises (such as low-profit Limited liability companies, benefit corps, flexible purpose corps, etc.) that attempt to balance profit and non-profit motives; but, there remain concerns regarding whether such mission-driven enterprises can effectively compete with standard for-profit enterprises in the absence of strong regulations [26]. However, others propose the primary factors that determine whether for-profit private enterprises enable or hinder sustainability is the inherent structure of their business models, as it can lead to unsustainable business practices when they suffer from information or alignment inefficiencies. Information inefficiencies occur when business decisions are made without complete or correct information. Alignment inefficiencies manifest when the objectives of decision makers in the business value chain are not compatible. Such inefficiencies can arguably be addressed through modification or innovation that restructures the decision making and value chain of a business 
model [22]. For this paper we follow this line of thinking to examine urban landscaping business models and consider how they may be modified to be more multifunctional and sustainable.

The predominant urban landscaping business models revolving around single purpose landscapes often have decision-making and value chains beset with information or alignment inefficiencies that leave them unable to sufficiently recognize unsustainable outcomes, whether for their customers, the landscapes, or society overall. Moreover, many business models lack integration of the additional financial or non-financial value creation and more sustainable outcomes that multifunctional landscapes could potentially provide [14,22]. However, rising awareness of multifunctional landscaping methods has led business entrepreneurs around the US to innovate new landscaping business models that can capture the value of multifunctional landscaping. Nevertheless, the question remains whether the values created by these new business models provide a sufficient business case at enterprise and city scales to support their widespread implementation. Our study attempts to address this question by examining the business case and models of several multifunctional landscaping enterprises operating in the Phoenix metro area of Arizona, and comparing them to conventional urban landscaping business models. To keep the scope of comparison manageable, as comprehensively exploring all potential multifunctional urban landscape possibilities would be an immense task, we focused our efforts on only examining multifunctional landscaping business models that specifically used "edible landscaping" methods. Edible landscaping (which has begun to be used as a specific term in the US, and is also known as foodscaping or agriscaping) refers to a landscaping methodology that integrates the aesthetic principles of ornamental landscape design with the productive principles of food gardening, replacing non-edible ornamental species with aesthetically attractive edible species [27]. We hypothesize that their use of multifunctional methods will enable the edible landscaping enterprises to better satisfy customer needs as well as enhance their resilience and competitive advantage compared to conventional counterparts. We also examine landscapes in the Phoenix metro area that the identified edible landscaping enterprises could likely target according to their business models, and the potential market value that could be produced from such landscapes. To be clear, we did not attempt to exhaustively examine all possible urban landscapes that could support edible function, as such a survey could be quite large, rather we only examined landscapes that were well suited to the identified edible landscaping business models.

\section{Materials and Methods}

To meet the objectives of this study we used a variety of methods for our examination of multifunctional edible landscaping business models and their business case. These methods included (1) semi-structured interviews with four landscaping enterprise owners, (2) a business model comparison of the four landscaping enterprises, (3) GIS landscape analysis of seven Phoenix metro area cities, and (4) value potential and return-on-investment (ROI) scenarios using data obtained from the interviews and GIS analysis. A methodological overview is provided in Figure 1.

\subsection{Entrepreneur Interviews and Business Model Comparison}

For the interviews and business model comparison, our aim was not to comprehensively establish the degree that conventional landscaping is different from multifunctional edible landscaping, but rather to identify differences that do exist and what they indicate for competitive advantage. The framework used as the foundation for developing interview questions and conducting the business model comparison was the Business Model Canvas (BMC), which is a popular strategic tool for analyzing and developing business models. The BMC provides guiding questions and methods to deconstruct business models into nine key components: (1) Value Proposition; (2) Customer Segments; (3) Customer Relationship; (4) Channels; (5) Key Resource; (6) Key Activities; (7) Key Partners; (8) Cost Structure, and; (9) Revenue Stream [28].

We identified, via word-of-mouth referral by ASU colleagues and local acquaintances, four Phoenix metro area landscaping entrepreneurs and interviewed them on their enterprise business 
models (Table 1). Each enterprise was selected to satisfy one of four "archetypes" defined by the authors: (1) conventional; (2) established multifunctional; (3) mixed or transitioning conventional-multifunctional; (4) post-transition multifunctional.

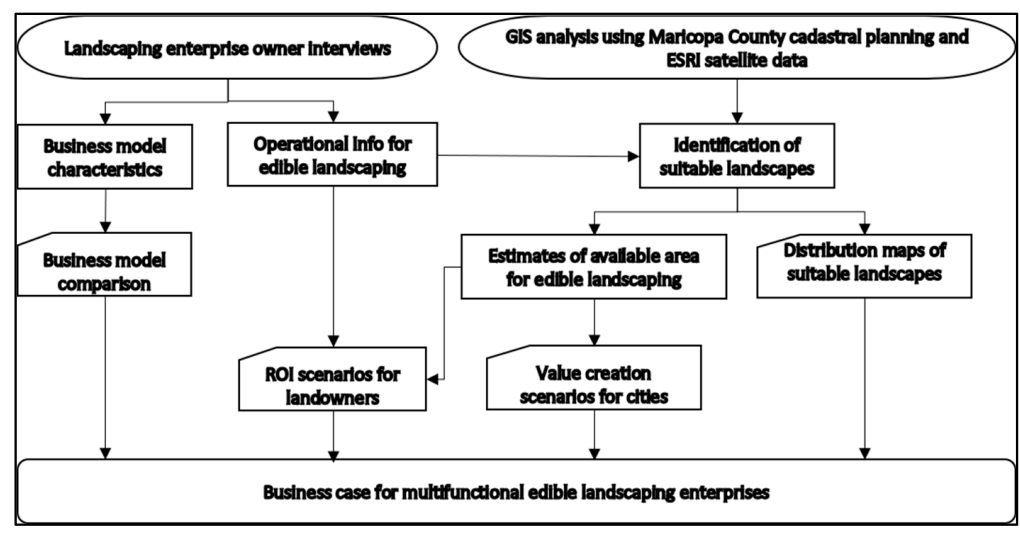

Figure 1. Methodological overview of business case analysis.

Table 1. Characteristics of Interviewed Enterprises.

\begin{tabular}{ccccc}
\hline & Enterprise A & Enterprise B & Enterprise C & Enterprise D \\
\hline Business Model & Conventional & Multifunctional & Mixed & Multifunctional \\
\hline Landscaping Services Offered & Organic Conventional & Edible & Conventional or Edible & Edible \\
\hline Full-time Employees & 3 & 17 & $40+$ & 1 \\
\hline
\end{tabular}

The first landscaping entrepreneur was franchise owner of an organic lawn care company, designated as Enterprise A, with three to four employees. Enterprise A was selected to act as a "conventional" single purpose landscaping business model example. While Enterprise A did possess characteristics that differentiated it from other "conventional" landscaping enterprises, namely, the use of organic lawn care products and electric lawn care equipment, the authors assumed that since the business model of Enterprise A did rely upon the maintenance of single purpose ornamental landscapes, it could still act as a viable proxy for "conventional" single purpose landscaping enterprises.

The second landscaping entrepreneur operated an edible landscaping company, designated as Enterprise B, with 17 employees. Enterprise B was selected to act as the "established" multifunctional landscaping business model example. However, in addition to its edible landscaping operations, Enterprise $B$ also provided educational and administrative services to edible landscaping professionals around the US (with Enterprises $C$ and D being among their customers), making certain aspects of Enterprise B's business model difficult to compare with the other enterprises.

The third landscaping entrepreneur managed a full-service landscaping company, designated as Enterprise C, with over 40 employees. Enterprise $C$ had a business model that was predominately based upon single purpose ornamental landscaping, but had incorporated edible landscaping as an expansion of its original business model. This allowed Enterprise $C$ to provide comparison of single purpose and multifunctional landscaping models within the same organizational context, as well as acting as a "transitionary" business model example.

The fourth landscaping entrepreneur worked as an independent landscaping contractor, designated as Enterprise D, who sub-contracted additional workers as needed. The entrepreneur of Enterprise D had previously worked for landscaping enterprises using single purpose landscaping business models, but upon becoming an independent contractor, he chose to pursue an edible landscaping business model. This allowed for Enterprise D to act as a "post-transition" business model example. 


\subsection{GIS Analysis and Scenarios}

Our aim for the GIS analysis and scenarios was obtain estimates that could roughly indicate market potential for edible landscaping in the Phoenix metro area. For the GIS analysis, 2015 cadastral land parcel survey data from Maricopa County Assessor's Office was obtained via the ASU GIS Data Repository [29]. ArcGIS software was used to isolate pertinent data for land parcels located within the seven largest cities by population in Maricopa County: (1) Phoenix; (2) Mesa; (3) Chandler; (4) Glendale; (5) Scottsdale; (6) Gilbert, and; (7) Tempe. The isolated cadastral data was then analyzed in tandem with visual inspection of satellite images using ESRI World Imagery (2015, 0.3 resolution) accessed through ArcGIS Online to identify landscape types and parcels that were suited for conversion into multifunctional edible landscapes [30]. The visual inspection involved examining purposive samples (informed by author familiarity of urban landscape characteristics) of parcels from various types (15 30 parcels of each type) to determine how well they aligned with selection criteria. The selection criteria for suitable landscapes, which was structured around landscapes the edible landscaping enterprises would likely target with their existing business models, was as follows:

1. Total area of convertible landscape type (collective sum of all landscape parcels of that type) within a city area exceeds 30 acres $\left(0.12 \mathrm{~km}^{2}\right)$. Criteria purpose is to ensure sufficient land area of the particular type to achieve return on investment for an edible landscaping enterprise.

2. Landscape type shows tendency to neighbor other landscape types suitable for conversion (whether of the same landscape type or another landscape type determined to be suitable). Criteria purpose is to allow for complementary landscape synergy and resource efficiency gains for an edible landscaping enterprise.

3. The landscape type already receives significant landscaping inputs (water, maintenance, etc.). Criteria purpose is to represent existing landowner interest and willingness to pay for landscaping service.

4. Landscape type has low ratio of impervious surfaces and high ratio of ornamental landscaping. Criteria purpose is to represent feasibility and ease of landscape modification by an edible landscaping enterprise.

Once suitable landscape types and parcels were identified using selection criteria and visual inspection, the available landscaping area for each landscape type was estimated by extracting and tabulating landscape parcel area data contained in the cadastral survey files, with livable area or area occupied by buildings (which was also included in the survey files) subtracted. Additionally, choropleth maps showing the distribution of suitable landscape types and parcels in the seven cities were produced. Then using the GIS data in tandem with anecdotal operational information provided by Enterprise B and Enterprise D, value creation scenarios for multifunctional edible landscaping in the seven cities of interest was estimated, as well as return on investment (ROI) scenarios for properties of average size. The formulas used to generate the value creation and ROI scenarios were as follows:

$$
\begin{gathered}
\text { (Area of landscape in sq. } \mathrm{ft} .) \times(\text { Percentage harvestable }) \times(\text { annual value per sq. } \mathrm{ft} .)=\text { Potential value, } \\
(\text { Installation cost })+(\text { Monthly maintenance cost }) \times(\# \text { of months after installation })=\text { Investment, }
\end{gathered}
$$

$$
(((\text { Landscape Area }) \times(\% \text { harvestable })) \times(\$ \text { per sq. ft. monthly })) \times(\# \text { of Months after installation })=\text { Return }
$$

\subsection{Methodological Limitations}

Before discussing results, we would like to acknowledge several methodological limitations that admittedly constrain the reliability and validity of the findings. First, with a sample size of only four enterprises, the collected interview information cannot be considered truly representative of the subsets of edible or multifunctional landscaping enterprises, much less the superset of landscaping 
enterprises in general. Second, the business model and operational information provided by the interviewed enterprises cannot be considered unbiased, as the enterprises have clear incentives to present their business models as being viable, and we were unable to collect directly verifiable business model and operational data. While we attempted to compensate for overt bias by cross comparing information between the different interviews (which were conducted separately) and comparing the obtained information with similar academic and anecdotal accounts of urban agriculture and edible landscaping, which indicated that the information provided was at least theoretically possible, even if at times seeming overly optimistic, ultimately the gathered information can only be considered anecdotal data [31-35]. Third, the Maricopa County cadastral land survey data used for our GIS analysis, being a database that is constantly updated and modified over time, likely contains many human input errors that could have distorted our results and induced a significant margin of error. Fourth, considering the total number of land parcels and landscape types in Phoenix metro area, the parcels that were visually inspected through satellite images are arguably insufficient to be considered a representative sample of the selected landscape types. Finally, the value creation and ROI scenarios are very simplified, precluding a multitude of contextual factors (such as soil quality, water rates, city or homeowner association (HOA) policies, etc.) at both city and individual landscape scales that could significantly impact harvest values and operational costs.

\section{Results}

\subsection{Business Model Comparison}

As described in the methods, we used the Business Model Canvas (BMC) approach to frame our comparison of the four enterprises. The comparison is broken into nine aspects: (1) Value Proposition; (2) Customer Segments; (3) Channels; (4) Customer Relationship; (5) Revenue Stream; (6) Key Resources; (7) Key Activities; (8) Key Partners, and; (9) Cost Structure (Table 2).

Value Propositions are the particular combination of services, products, and characteristics that a business model uses to distinguish itself from competitors. While each enterprise possessed a variety of value propositions, our comparison indicates that offering edible landscaping allowed the examined enterprises to offer a wider range of value propositions than if they only offered conventional landscaping.

Customer Segments are how a business model distinguishes between customers in order to better meet their different needs. All the enterprises had both similarities and differences in customer segments, but the edible landscaping enterprises were able to target customer segments uninterested in conventional landscaping, such as do-it-yourself (DIY) gardeners and food retailers.

Channels are the methods that a business model uses to communicate and deliver their value propositions to their customers. Channels can be divided into five stages of value propositions communication and delivery: (1) Awareness; (2) Evaluation; (3) Purchase; (4) Delivery; and (5) After Sales. There was a diversity of channels used by all the enterprises, both electronic and in-person, but in our comparison the edible landscaping correlated more with in-person channels than conventional landscaping.

Customer Relationships refers to the kind of social interactions that take place between the customers and the business. The customer relationships were mostly similar between the enterprises; however, edible landscaping had self-service relationships that we did not find with conventional landscaping.

Revenue Streams are the activities that generate income for the business, and are usually what the customer segments are paying to receive. Although the primary revenue streams were similar between the enterprises, the comparison shows that edible landscaping allows access to a greater number of revenue streams than conventional landscaping, such as revenue generated from the sale of edible products to food retailers or training DIY gardeners. 
Table 2. Business Model Comparison of Interviewed Enterprises.

\begin{tabular}{|c|c|c|c|c|}
\hline & $\begin{array}{c}\text { Enterprise A } \\
\text { (Conventional) }\end{array}$ & $\begin{array}{l}\text { Enterprise B } \\
\text { (Edible) }\end{array}$ & $\begin{array}{c}\text { Enterprise C } \\
\text { (Mixed) }\end{array}$ & $\begin{array}{l}\text { Enterprise D } \\
\text { (Edible) }\end{array}$ \\
\hline Value Proposition & $\begin{array}{l}\text { Reliable and considerate service } \\
\text { Electric equipment with no emissions } \\
\text { and minimal noise } \\
\text { Organic practices using no harmful } \\
\text { chemicals } \\
\text { Insured service }\end{array}$ & $\begin{array}{c}\text { Elegant edible landscaping } \\
\text { Offset landscaping costs and make landscape } \\
\text { profitable } \\
\text { Fresh, healthy food } \\
\text { Either do-it-yourself (DIY) or full-service } \\
\text { options } \\
\text { Training and certification } \\
\text { Continuing education } \\
\text { Improve competitive advantage of } \\
\text { landscaping business } \\
\text { Management and administrative assistance } \\
\text { Referrals }\end{array}$ & $\begin{array}{l}\text { Wide range of landscaping services } \\
\text { Quality landscaping work } \\
\text { Great customer service } \\
\text { Create your vision } \\
\text { Edible landscaping * } \\
\text { Offset landscaping costs * } \\
\text { Supplemental food * } \\
\text { Self-reliance * }\end{array}$ & $\begin{array}{c}\text { Achieve the edible landscaping that you } \\
\text { want } \\
\text { Considerate of customer needs and } \\
\text { limitations } \\
\text { Make landscape profitable } \\
\text { Fresh, healthy food } \\
\text { Either DIY training or full-service options }\end{array}$ \\
\hline Customer Segments & $\begin{array}{c}\text { Residential } \\
\text { Commercial (Small) }\end{array}$ & $\begin{array}{c}\text { DIY gardeners } \\
\text { Edible landscaping professionals } \\
\text { Residential } \\
\text { Commercial } \\
\text { Public } \\
\text { Food retailers }\end{array}$ & $\begin{array}{l}\text { Commercial } \\
\text { Residential } \\
\text { Housing developers } \\
\text { DIY gardeners * }\end{array}$ & $\begin{array}{l}\text { Residential } \\
\text { DIY gardeners } \\
\text { Food retailers }\end{array}$ \\
\hline $\begin{array}{l}\text { Channels: } \\
\text { Awareness } \\
\text { Evaluation } \\
\text { Purchase } \\
\text { Delivery } \\
\text { After sales }\end{array}$ & $\begin{array}{l}\text { Website Google search ranking, flyers } \\
\text { Free quote visit } \\
\text { Cash, check, online payment (monthly) } \\
\text { Scheduled weekly or biweekly visits } \\
\text { Email newsletter }\end{array}$ & $\begin{array}{l}\text { Educational presentations, social media, } \\
\text { website, local news coverage } \\
\text { Tour with meal } \\
\text { Online payment (monthly, payment plans) } \\
\text { Web/mobile platform, on-site classes, } \\
\text { scheduled visits } \\
\text { Monthly email newsletter, 4- to 6-month } \\
\text { follow-up }\end{array}$ & $\begin{array}{c}\text { Word of mouth, customer referrals, } \\
\text { website } \\
\text { Sales team } \\
\text { Check, online payment (within } \\
30 \text { days, payment plans) } \\
\text { Scheduled visits } \\
\text { Periodic contact to offer additional } \\
\text { services, encourage referrals } \\
\end{array}$ & $\begin{array}{l}\text { Word of mouth, networking events, } \\
\text { educational presentations } \\
\text { Example pictures, consultation } \\
\text { Cash, check, online payment (monthly) } \\
\text { As needed and on-request visits } \\
\text { Mentor relationship, sharing education } \\
\text { materials }\end{array}$ \\
\hline Customer Relationships & $\begin{array}{l}\text { Dedicated personal service } \\
\text { Co-creation }\end{array}$ & $\begin{array}{c}\text { Dedicated personal service } \\
\text { Co-creation } \\
\text { Community } \\
\text { Self-service } \\
\text { Automated services }\end{array}$ & $\begin{array}{l}\text { Dedicated personal service } \\
\text { Co-creation }\end{array}$ & $\begin{array}{c}\text { Dedicated personal service } \\
\text { Co-creation } \\
\text { Self-service }\end{array}$ \\
\hline Revenue Streams & $\begin{array}{l}\text { Maintenance fees } \\
\text { Installation fees } \\
\text { Mark-up (10-25\%) }\end{array}$ & $\begin{array}{c}\text { DIY training fees } \\
\text { Professional training fees } \\
\text { Installation fees } \\
\text { Consultation and Design fees } \\
\text { Maintenance fees } \\
\text { Edible sale }(15-55 \%) \\
\text { Administrative platform subscription fees } \\
\text { Referral fees } \\
\text { Markup ( } 33 \%)\end{array}$ & $\begin{array}{c}\text { Installation fees } \\
\text { Consultation and Design fees } \\
\text { Maintenance fees } \\
\text { Mark-up (10\% and higher) }\end{array}$ & $\begin{array}{l}\text { Maintenance fees } \\
\text { Edible sale (15-55\%) } \\
\text { Consultation and Design fees } \\
\text { DIY training fees } \\
\text { Installation fees }\end{array}$ \\
\hline
\end{tabular}


Table 2. Cont

\begin{tabular}{|c|c|c|c|c|}
\hline & $\begin{array}{c}\text { Enterprise A } \\
\text { (Conventional) }\end{array}$ & $\begin{array}{c}\text { Enterprise B } \\
\text { (Edible) }\end{array}$ & $\begin{array}{c}\text { Enterprise C } \\
\text { (Mixed) }\end{array}$ & $\begin{array}{c}\text { Enterprise D } \\
\text { (Edible) }\end{array}$ \\
\hline Key Resources & $\begin{array}{c}\text { Vehicle } \\
\text { Landscaping equipment and materials } \\
\text { Employees (landscapers) } \\
\text { General landscaping knowledge }\end{array}$ & $\begin{array}{c}\text { Web-based education and administrative } \\
\text { platform } \\
\text { Vehicles } \\
\text { Landscaping equipment and materials } \\
\text { Employees (educators, marketing, } \\
\text { accounting, programmers, landscapers) } \\
\text { General landscaping knowledge } \\
\text { Edible landscaping knowledge }\end{array}$ & $\begin{array}{c}\text { Vehicles } \\
\text { Landscaping equipment and } \\
\text { materials } \\
\text { Employees (project managers, } \\
\text { foremen, landscapers, sales, } \\
\text { administrative) } \\
\text { General landscaping knowledge } \\
\text { Edible landscaping knowledge * }\end{array}$ & $\begin{array}{c}\text { Vehicle } \\
\text { Landscaping equipment and materials } \\
\text { General landscaping knowledge. } \\
\text { Edible landscaping knowledge }\end{array}$ \\
\hline Key Activities & $\begin{array}{l}\text { Landscape maintenance } \\
\text { Landscape installation * } \\
\text { Administrative tasks } \\
\text { Marketing }\end{array}$ & $\begin{array}{c}\text { Education } \\
\text { Business development } \\
\text { Administrative tasks } \\
\text { Marketing } \\
\text { Landscape design and consultation } \\
\text { Landscape installation } \\
\text { Landscape maintenance } \\
\text { Harvesting edibles } \\
\text { Selling edibles }\end{array}$ & $\begin{array}{l}\text { Landscape design } \\
\text { Landscape installation } \\
\text { Landscape maintenance } \\
\text { Administrative tasks } \\
\text { Sales }\end{array}$ & $\begin{array}{c}\text { Landscape maintenance } \\
\text { Harvesting landscape } \\
\text { Selling edibles } \\
\text { Landscape design and consultation } \\
\text { Landscape installation } \\
\text { Education } \\
\text { Administrative tasks } \\
\text { Networking }\end{array}$ \\
\hline Key Partners & $\begin{array}{c}\text { Franchise network } \\
\text { Landscaping material vendors }\end{array}$ & $\begin{array}{l}\text { Certified edible landscaping professionals } \\
\text { Landscaping and educational organizations } \\
\text { Landscaping material vendors } \\
\text { Edible landscape owners } \\
\text { Fellow subsidiary food hub enterprise } \\
\text { Food retailers } \\
\end{array}$ & $\begin{array}{l}\text { Landscaping material vendors } \\
\text { Referring customers } \\
\text { Enterprise B }\end{array}$ & $\begin{array}{l}\text { Landscaping material vendors } \\
\text { Fruit grower organization } \\
\text { Edible landscape owners } \\
\text { Food retailers } \\
\text { Enterprise B }\end{array}$ \\
\hline Cost Structure & $\begin{array}{c}\text { Employees }(\$ 15 / \mathrm{h}) \\
\text { Franchise fee } \\
\text { Landscaping materials and equipment } \\
\text { Vehicle } \\
\text { Insurance } \\
\text { Advertising/Website } \\
\text { Utilities }\end{array}$ & $\begin{array}{c}\text { Programming } \\
\text { Employees }(\$ 14-\$ 35 / \mathrm{h}) \\
\text { Accounting/Legal } \\
\text { Marketing/Website } \\
\text { Landscaping materials and equipment } \\
\text { Vehicles } \\
\text { Utilities }\end{array}$ & $\begin{array}{l}\text { Landscaping materials and } \\
\text { equipment } \\
\text { Employees }(\$ 10-\$ 20 / \mathrm{h}) \\
\text { Insurance } \\
\text { Office space } \\
\text { Vehicles } \\
\text { Utilities and website }\end{array}$ & $\begin{array}{l}\text { Landscaping materials and equipment } \\
\text { Vehicle } \\
\text { Subcontracted employees }(\$ 10-\$ 15 / \mathrm{h}) \text { * } \\
\text { Utilities and website }\end{array}$ \\
\hline
\end{tabular}

${ }^{*}$ Limited in scope or confined to certain services. 
Key Resources are the critical human, physical, intellectual, and financial assets that enable a business to operate and deliver its particular value propositions to customers. The key resources used by the enterprises were found to be very similar, with the only apparent resource differences between edible and conventional landscaping being edible landscape care knowledge and landscape material selection.

Key Activities are the primary actions a business performs in order operate and deliver their value propositions. The comparison showed that edible landscaping can lead to carrying out more key activities than conventional landscaping, such as harvesting and selling edible products, although these activities could also be carried out by key partners instead.

Key Partners are the critical suppliers and complementary organizations that help a business operate successfully and deliver its value proposition effectively. From the comparison, edible landscaping required more key partners than conventional landscaping, among which the partners that assisted with the marketing, distribution, and sale of harvested edibles were crucial for maximizing the value obtained from the edibles.

Cost Structure addresses the important operational costs that a business accumulates while delivering its value proposition, which can be either fixed or variable, although this distinction is disregarded for this comparison. The overall cost structures between the enterprises were similar, with no clear correlation for differences, although there were indications that employee pay for edible landscaping was higher than for conventional landscaping.

\subsection{GIS Analysis}

From the Maricopa County cadastral land survey data, four landscape types that sufficiently matched the criteria for multifunctional use were identified. The four landscape types, along with their associated Property Use Codes (PUC), were Single Family Residential (01- -, 85 subcategories), Residential Open Space (0261), Municipal Parks (9750), and Municipal Schools (9790). First, the total area of each landscape type within the respective cities all exceeded 30 acres $\left(0.12 \mathrm{~km}^{2}\right)$, although within the cities of Tempe and Scottsdale, the area of Municipal Schools came close to failing this criterion. Second, all four of the landscape types were found to consistently neighbor each other, with Single Family Residential comprising the primary agglomerations and the other landscape types located within or bordering the clusters of Single Family Residential. Third, visual inspections of the four landscape types showed that they consistently featured existing well-maintained landscaping (e.g., green lawns, mature trees, trimmed shrubbery, etc.). Fourth, all four landscape types reliably possessed low ratios of impervious surfaces (approx. 30\% or less) such as concrete and asphalt, as well as featuring high ratios of landscaping area that appeared to be primarily ornamental (approx. 30\% or more), such as empty lawns and dense shrubbery.

The approximate area in acres and distribution of each identified landscape type, with livable area excluded, for the seven selected cities are compiled into a table (Table 3) and displayed in choropleth maps according to city boundaries, which include Phoenix (Figure 2), Scottsdale (Figure 3), Mesa (Figure 4), Gilbert (Figure 5), Chandler (Figure 6), Glendale (Figure 7), and Tempe (Figure 8).

Table 3. Suitable Multifunctional Edible Landscape Area in Acres (Livable area excluded).

\begin{tabular}{cccccc}
\hline & Single Family & Res Open Space & Municipal Park & Municipal School & Total \\
\hline \multirow{2}{*}{ Phoenix } & $\sim 58,230$ & $\sim 10,436$ & $\sim 4700$ & $\sim 415$ & $\sim 73,781$ \\
& $\left(235.65 \mathrm{~km}^{2}\right)$ & $\left(42.23 \mathrm{~km}^{2}\right)$ & $\left(19.02 \mathrm{~km}^{2}\right)$ & $\left(1.68 \mathrm{~km}^{2}\right)$ & $\left(298.58 \mathrm{~km}^{2}\right)$ \\
\hline \multirow{2}{*}{ Scottsdale } & $\sim 24,251$ & $\sim 11,996$ & $\sim 959$ & $\sim 39$ & $\sim 37,245$ \\
& $\left(98.14 \mathrm{~km}^{2}\right)$ & $\left(48.55 \mathrm{~km}^{2}\right)$ & $\left(3.88 \mathrm{~km}^{2}\right)$ & $\left(0.16 \mathrm{~km}^{2}\right)$ & $\left(150.73 \mathrm{~km}^{2}\right)$ \\
\hline \multirow{2}{*}{ Mesa } & $\sim 18,144$ & $\sim 3902$ & $\sim 970$ & $\sim 282$ & $\sim 23,298$ \\
& $\left(73.43 \mathrm{~km}^{2}\right)$ & $\left(15.79 \mathrm{~km}^{2}\right)$ & $\left(3.93 \mathrm{~km}^{2}\right)$ & $\left(0.08 \mathrm{~km}^{2}\right)$ & $\left(94.28 \mathrm{~km}^{2}\right)$ \\
\hline \multirow{2}{*}{ Gilbert } & $\sim 12,208$ & $\sim 3592$ & $\sim 400$ & $\sim 101$ & $\sim 16,301$ \\
& $\left(49.40 \mathrm{~km}^{2}\right)$ & $\left(14.54 \mathrm{~km}^{2}\right)$ & $\left(1.62 \mathrm{~km}^{2}\right)$ & $\left(0.41 \mathrm{~km}^{2}\right)$ & $\left(65.97 \mathrm{~km}^{2}\right)$ \\
\hline
\end{tabular}


Table 3. Cont.

\begin{tabular}{cccccc}
\hline & Single Family & Res Open Space & Municipal Park & Municipal School & Total \\
\hline \multirow{2}{*}{ Chandler } & $\sim 10,182$ & $\sim 3092$ & $\sim 534$ & $\sim 76$ & $\sim 13,884$ \\
& $\left(41.21 \mathrm{~km}^{2}\right)$ & $\left(12.51 \mathrm{~km}^{2}\right)$ & $\left(2.16 \mathrm{~km}^{2}\right)$ & $\left(0.31 \mathrm{~km}^{2}\right)$ & $\left(56.19 \mathrm{~km}^{2}\right)$ \\
\hline \multirow{2}{*}{ Glendale } & $\sim 8713$ & $\sim 838$ & $\sim 1305$ & $\sim 197$ & $\sim 11,053$ \\
& $\left(35.26 \mathrm{~km}^{2}\right)$ & $\left(3.39 \mathrm{~km}^{2}\right)$ & $\left(5.28 \mathrm{~km}^{2}\right)$ & $\left(0.80 \mathrm{~km}^{2}\right)$ & $\left(44.73 \mathrm{~km}^{2}\right)$ \\
\hline \multirow{2}{*}{ Tempe } & $\sim 5118$ & $\sim 428$ & $\sim 400$ & $\sim 38$ & $\sim 5984$ \\
& $\left(20.71 \mathrm{~km}^{2}\right)$ & $\left(1.73 \mathrm{~km}^{2}\right)$ & $\left(1.62 \mathrm{~km}^{2}\right)$ & $\left(0.15 \mathrm{~km}^{2}\right)$ & $\left(24.22 \mathrm{~km}^{2}\right)$ \\
\hline \multirow{2}{*}{ Total } & $\sim 136,846$ & $\sim 34,284$ & $\sim 9268$ & $\sim 1148$ & $\sim 181,546$ \\
& $\left(553.80 \mathrm{~km}^{2}\right)$ & $\left(138.74 \mathrm{~km}^{2}\right)$ & $\left(37.51 \mathrm{~km}^{2}\right)$ & $\left(4.65 \mathrm{~km}^{2}\right)$ & $\left(734.69 \mathrm{~km}^{2}\right)$ \\
\hline
\end{tabular}

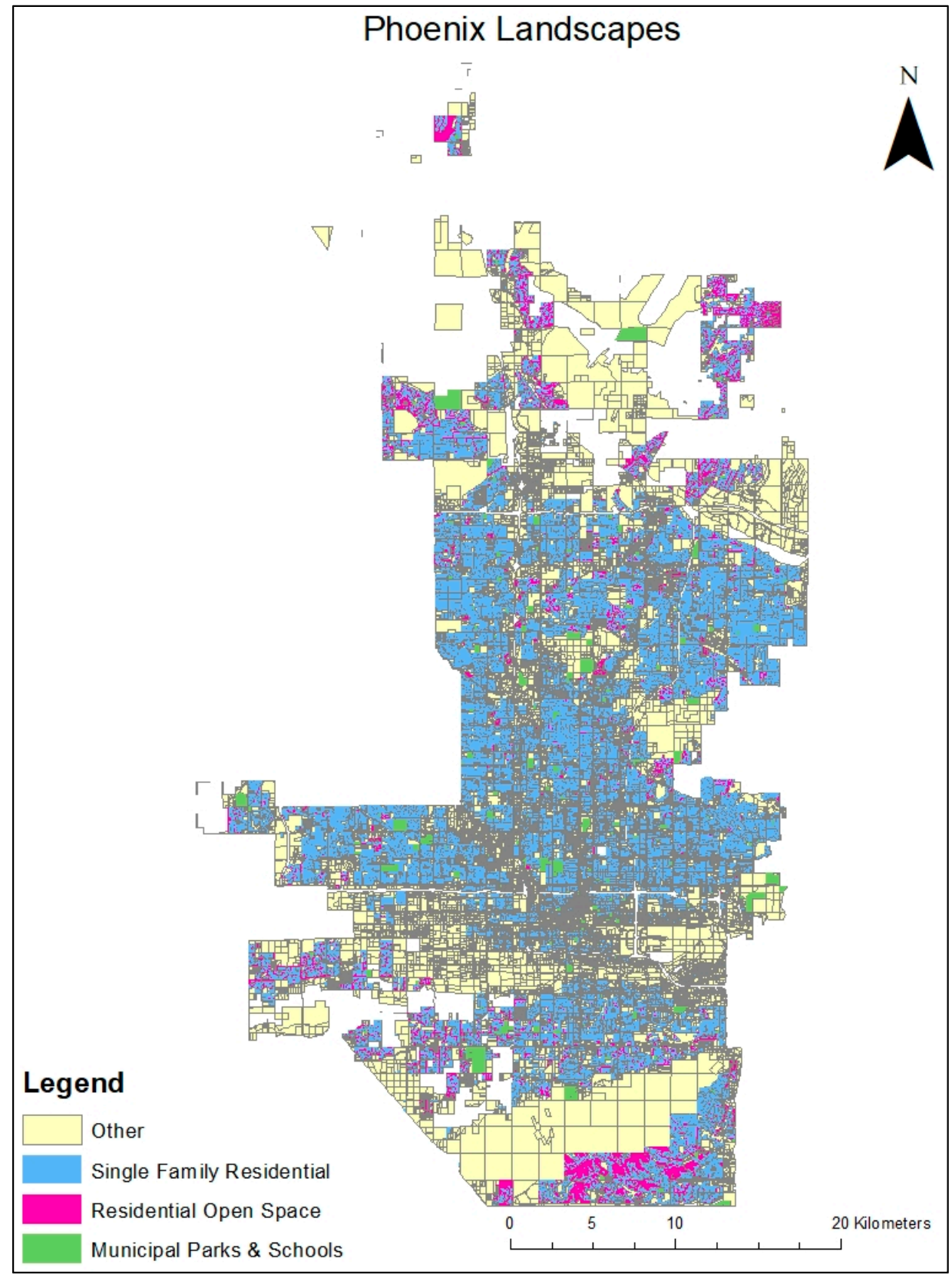

Figure 2. Distribution of identified landscapes in Phoenix. 


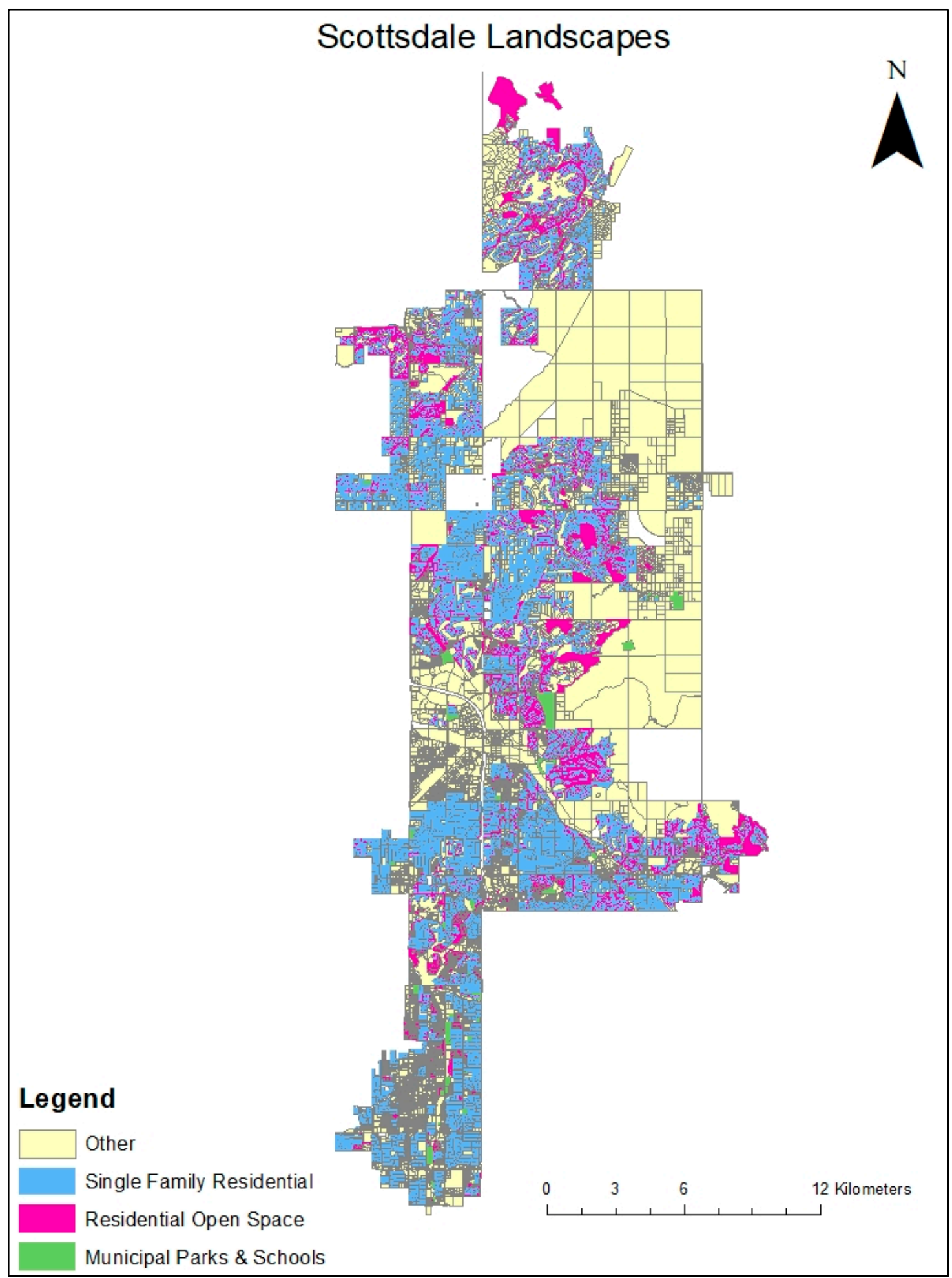

Figure 3. Distribution of identified landscapes in Scottsdale. 


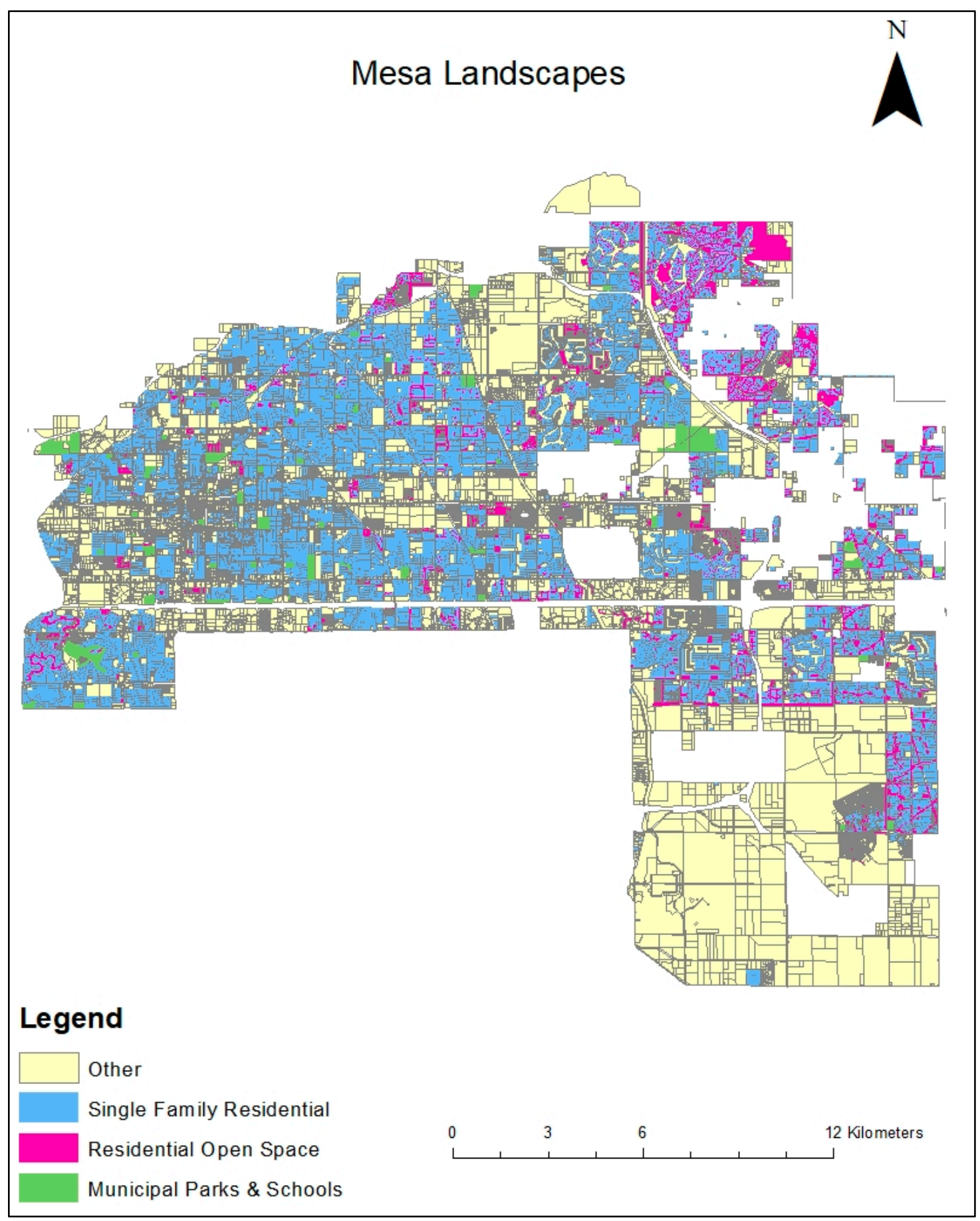

Figure 4. Distribution of identified landscapes in Mesa. 


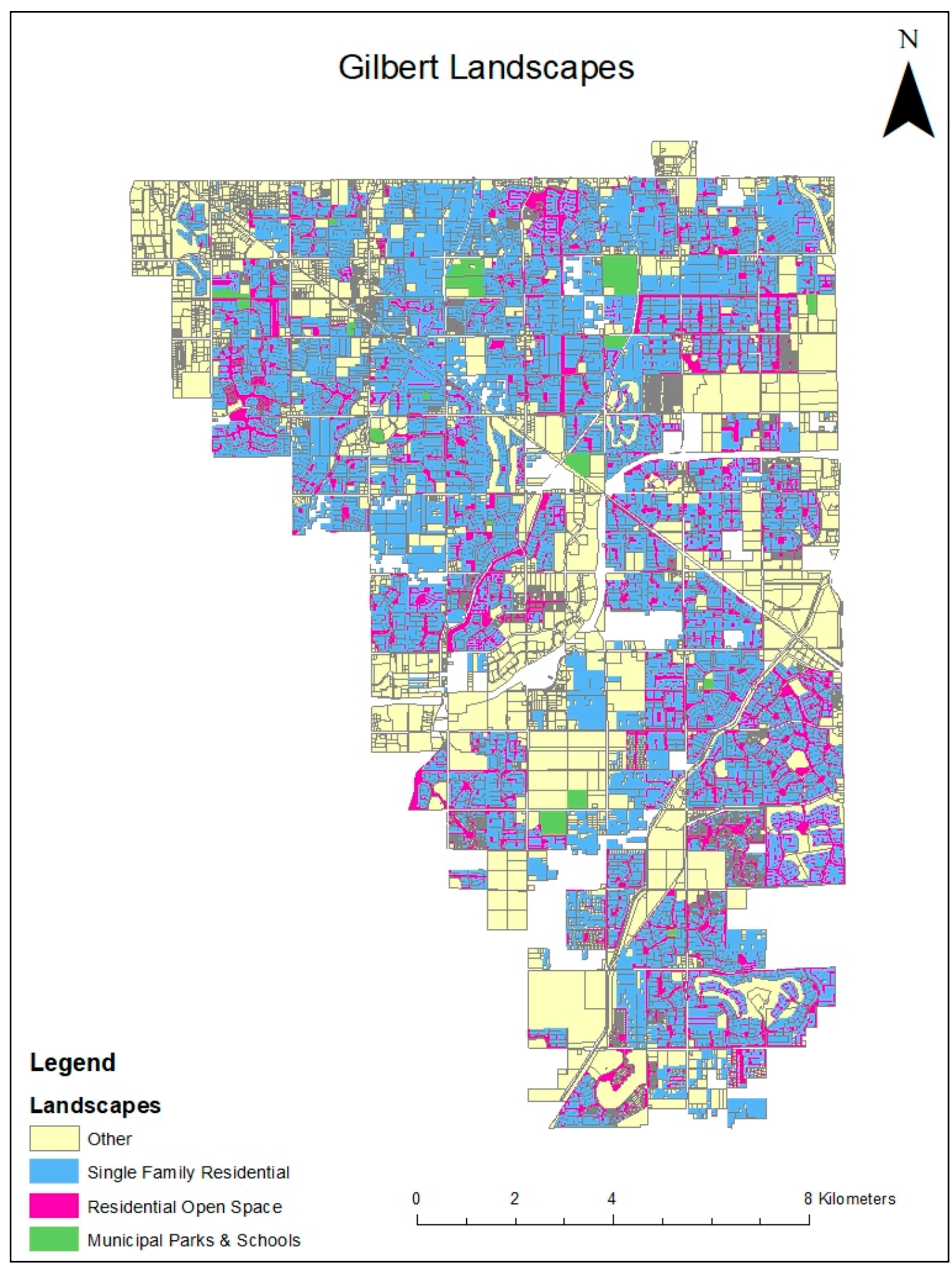

Figure 5. Distribution of identified landscapes in Gilbert. 


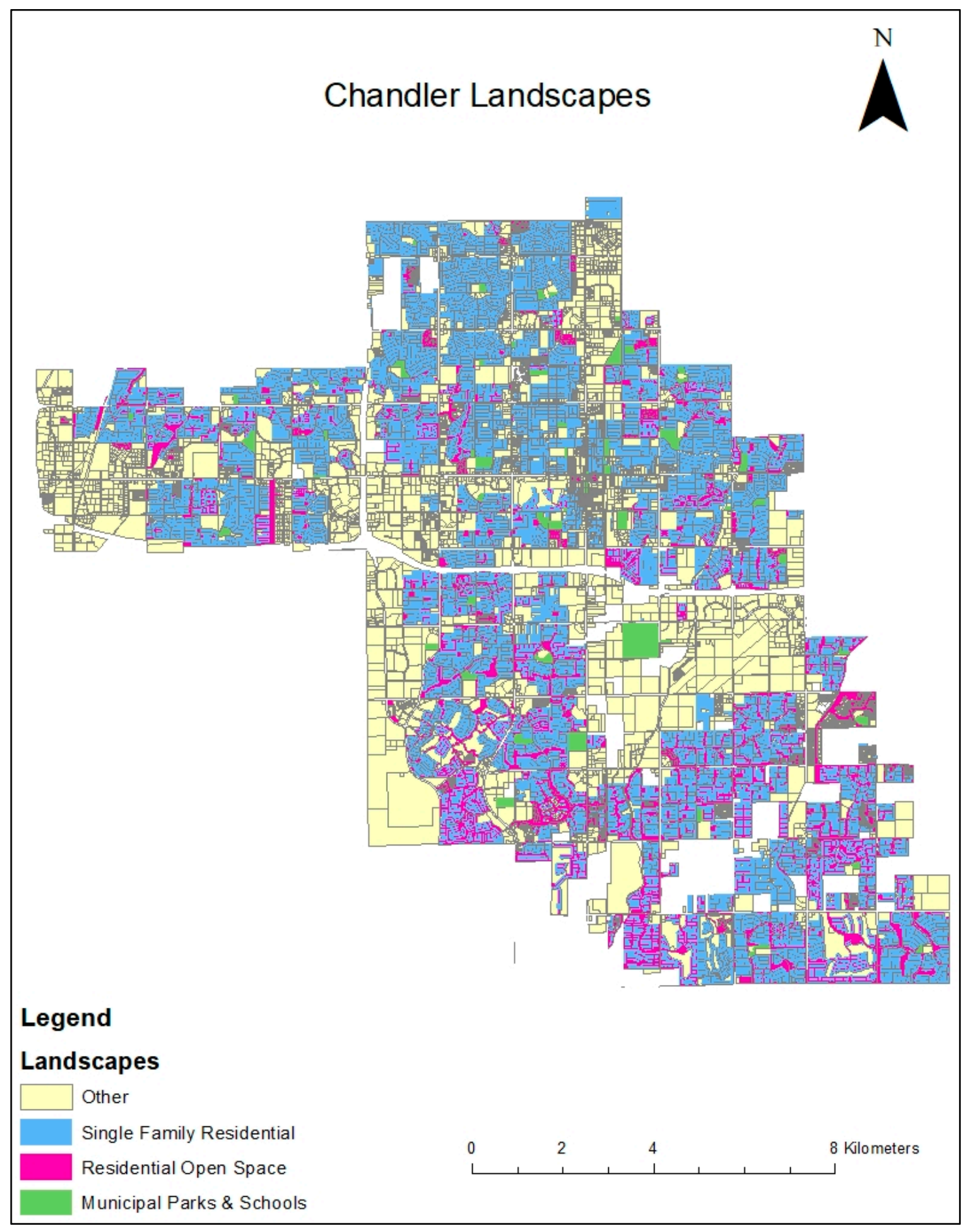

Figure 6. Distribution of identified landscapes in Chandler. 


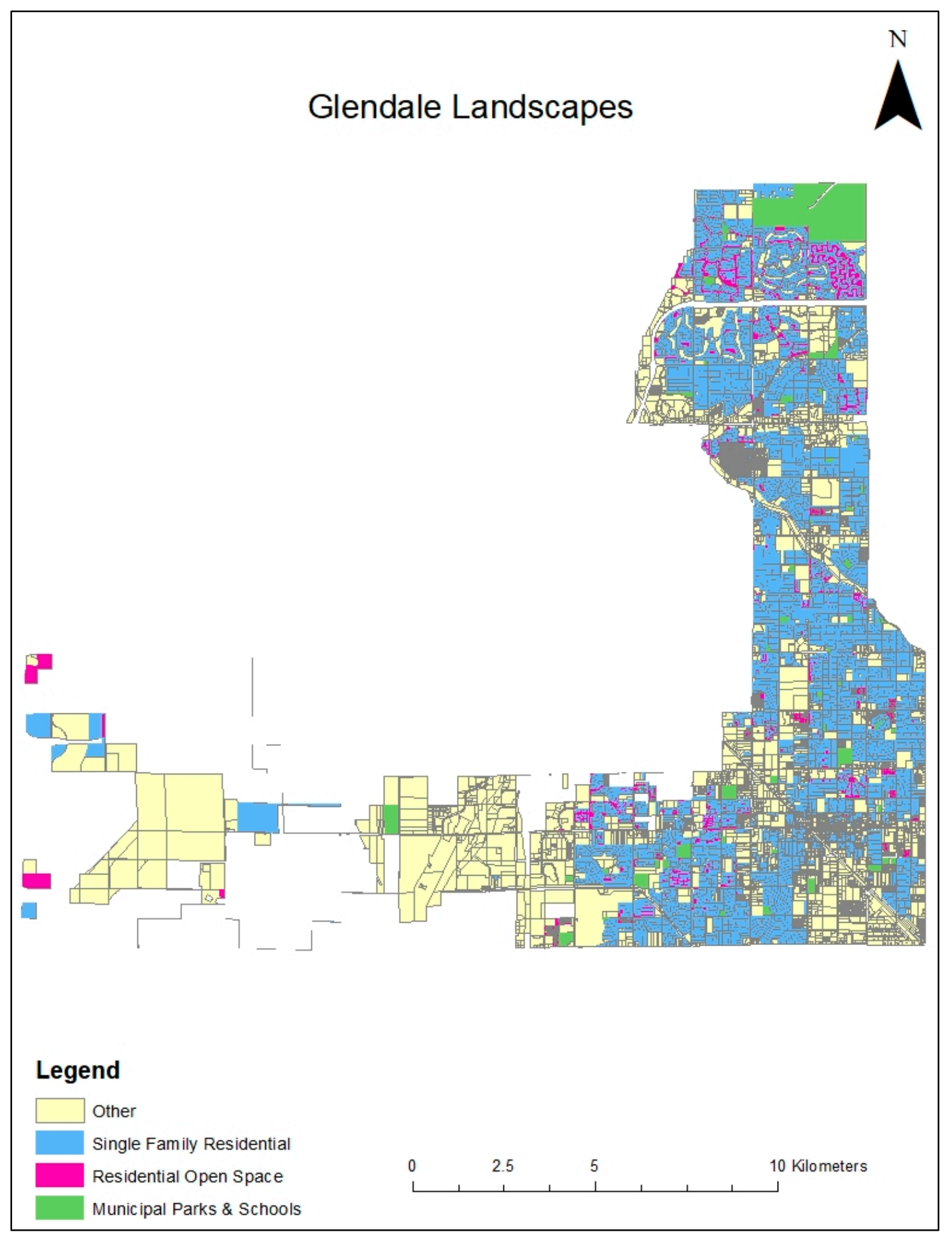

Figure 7. Distribution of identified landscapes in Glendale. 


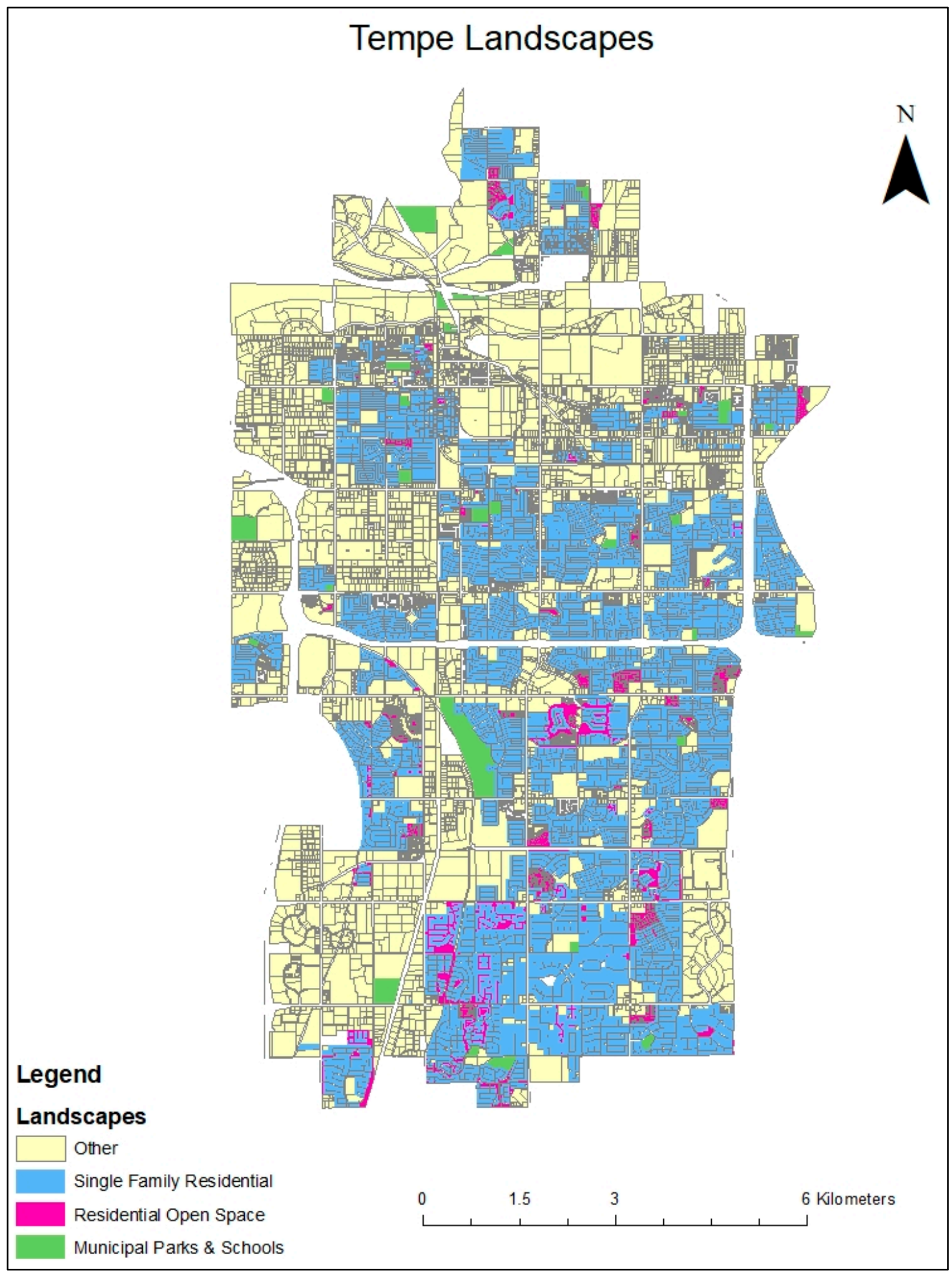

Figure 8. Distribution of identified landscapes in Tempe.

\subsection{Value Creation Scenarios}

The GIS analysis results indicated that there are approximately 181,546 acres $\left(734.69 \mathrm{~km}^{2}\right)$ of landscape area in the seven examined cities that could be suitable for multifunctional landscaping. To estimate the new value creation that could be achieved from making these landscapes 
multifunctional, the edible landscaping methodology and operational data provided by Enterprise B was used as the basis for our calculations and assumptions.

The edible landscaping designs by Enterprise B usually devoted approximately $22.5 \%$ of the landscape area to producing harvestable edibles, while the remaining landscape area either retains the ornamental or recreational functions of conventional landscaping or is unusable due to being covered by impervious surfaces. Depending on the type and density of the edibles grown, the gross value obtained from harvested edibles produced by Enterprise B landscapes annually per square foot could range from $\$ 5$ to $\$ 24$, with $\$ 10$ per sq. $\mathrm{ft}$. annually being the overall average. Enterprise $\mathrm{B}$ achieved these harvest value amounts via collaboration with a fellow subsidiary food hub enterprise that facilitated successful sale of the harvests through farmers markets and food delivery services. Combining the GIS landscape area estimates for the seven cities with the harvest value estimates, we calculated 12 potential annual value scenarios, varying the percentage of harvestable landscape $(10 \%$, $22.5 \%, 35 \%$ ) and value produced per sq. $\mathrm{ft}$. annually $(\$ 5, \$ 10, \$ 15, \$ 24)$, that could result through the use of edible landscaping.

The scenario results (Figures 9-12) show that under the various conditions, converting the identified landscapes into edible landscaping could theoretically create between $\$ 3.9$ and $\$ 66$ billion in additional value for the Phoenix metro area. Of course, whether such amounts of new value creation could actually be achieved depends on many variables; nevertheless, the analysis highlights the untapped potential of edible landscaping.

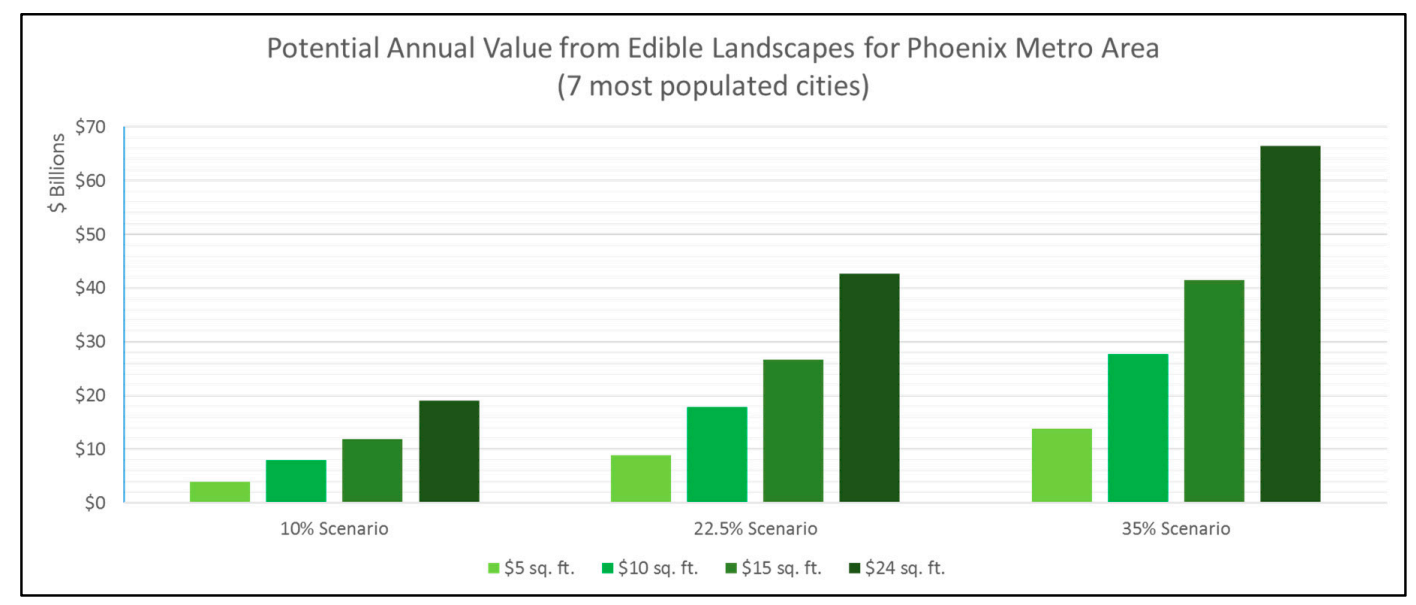

Figure 9. Potential annual value from edible landscapes for Phoenix Metro Area.

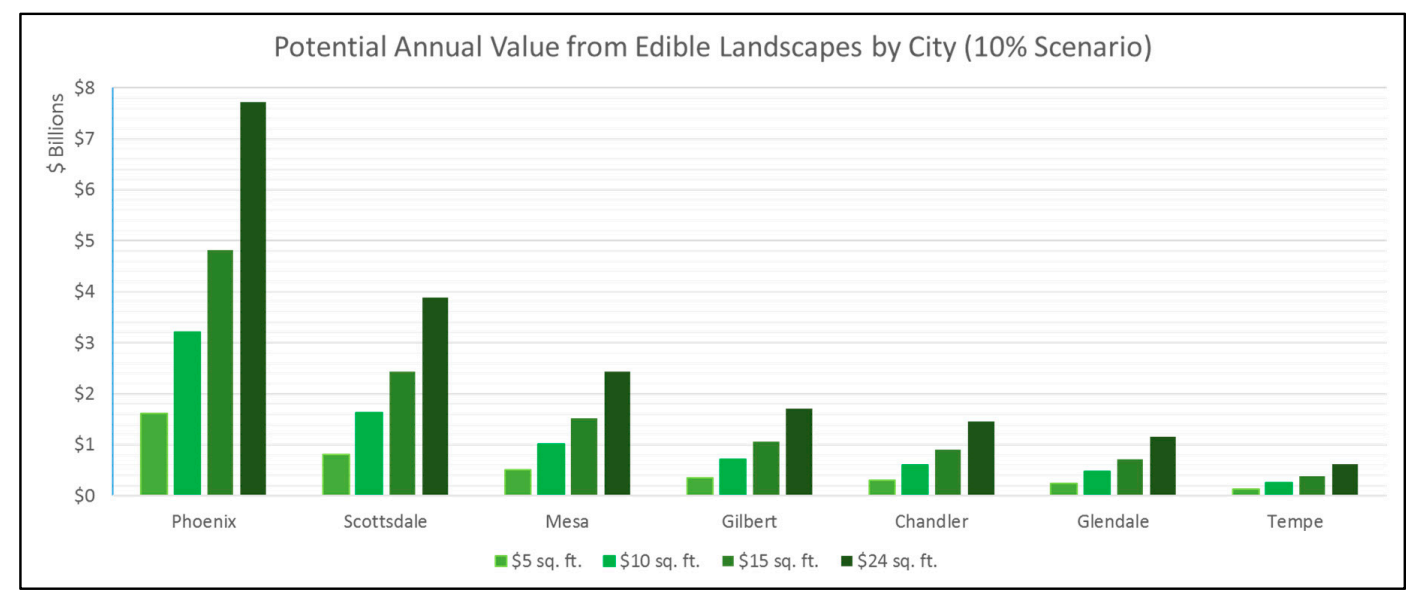

Figure 10. Potential annual value from edible landscapes by city (10\% scenario). 


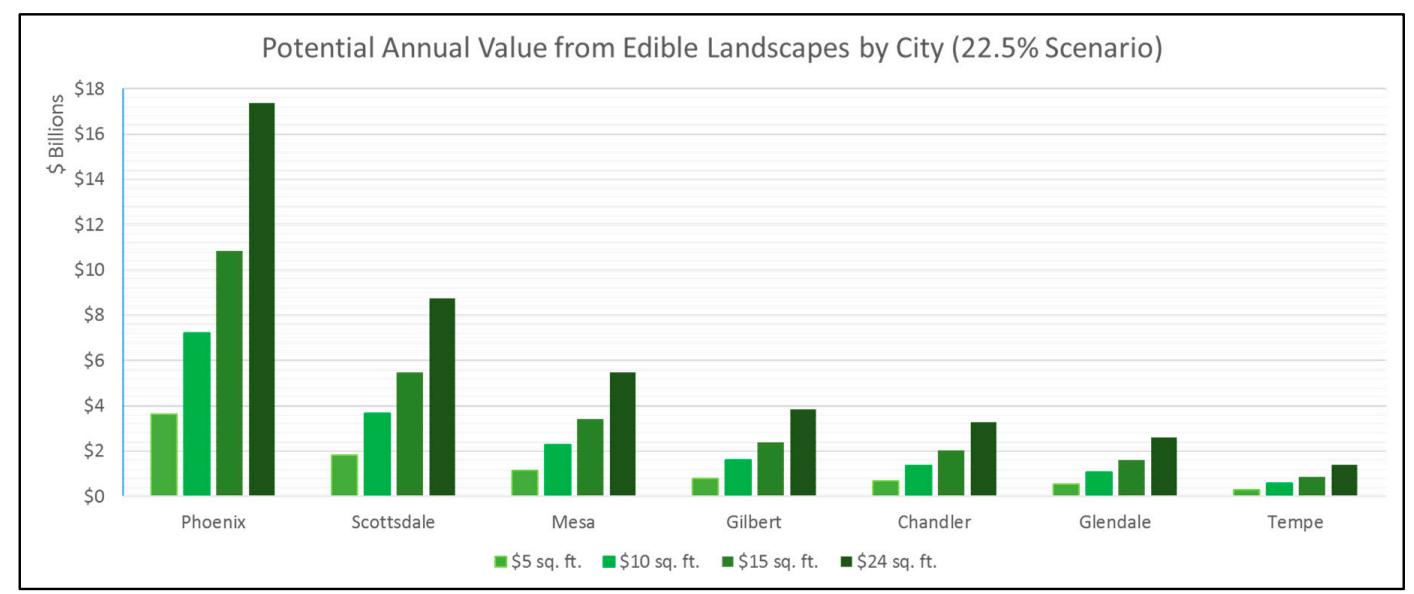

Figure 11. Potential annual value from edible landscapes by city (22.5\% scenario).

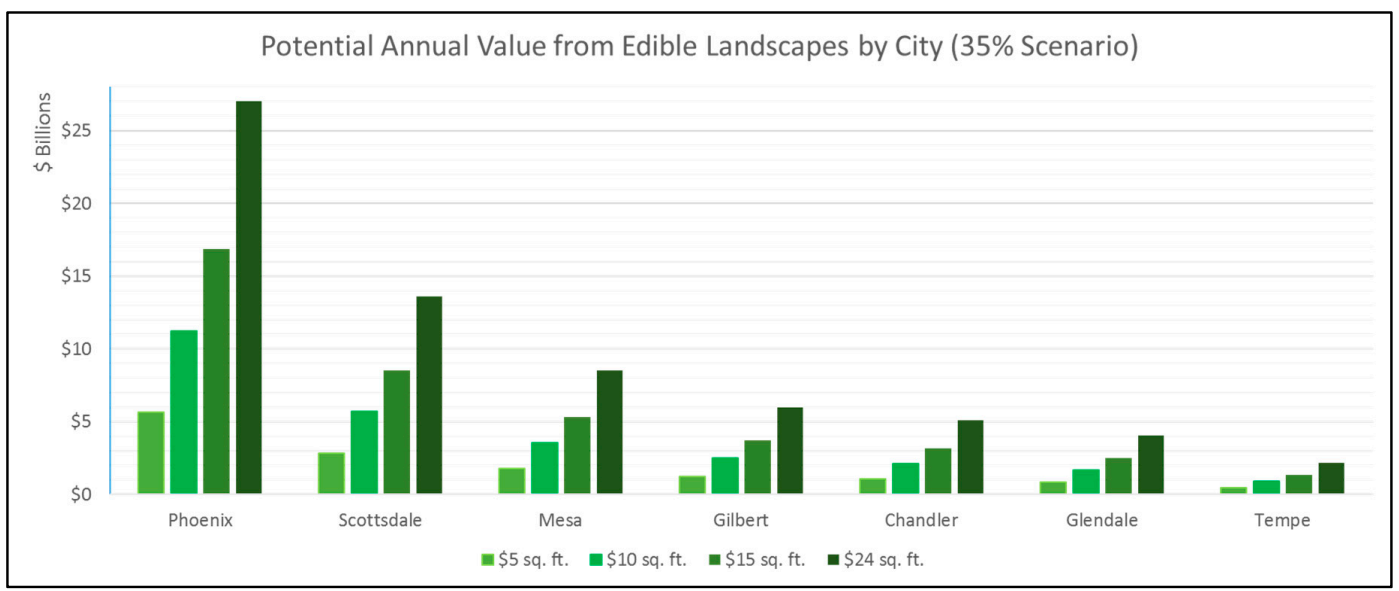

Figure 12. Potential annual value from edible landscapes by city ( $35 \%$ scenario).

\subsection{ROI Scenarios}

When considering the potential value creation of edible landscaping at the individual parcel level, one method is to estimate the return on investment (ROI) for a landowner installing edible landscaping. We again use the edible landscaping methodology and operational data of Enterprise B as the basis for calculations and assumptions.

According to the collected GIS data, the average landscape area (excluding livable area) for a single family residential parcel in the Phoenix metro area falls between 6000 and $8000 \mathrm{sq}$. ft. (557.42 to $743.22 \mathrm{~m}^{2}$ ). According to Enterprise B, the average cost for their 6000 to $8000 \mathrm{sq}$. ft. landscaping installation projects comes to approximately $\$ 17,000$, with $22.5 \%$ of the landscape being harvestable. Additionally, Enterprise B would charge around \$250 per month (four visits of two hours each) for full service maintenance of such a landscape. Using this information, we calculated 12 ROI scenarios, varying the percentage of harvestable landscape $(10 \%, 22.5 \%, 35 \%)$ and value produced per sq. ft. annually ( $\$ 5, \$ 10, \$ 15, \$ 24)$, assuming a landscaped area of $7000 \mathrm{sq}$. ft. $\left(650.32 \mathrm{~m}^{2}\right)$ and including both installation $(\$ 17,000)$ and maintenance costs $(\$ 250$ per month). We also assumed it would take three months after the installation is finished before any edibles could be harvested.

The results (Figures 13-15) show that all but one scenario is able to achieve a positive ROI, with the exception being the $(10 \% \& \$ 5)$ scenario which operates at a loss. The remaining scenarios all achieve a positive ROI within five years or less. The $(10 \%$ and $\$ 10)$ scenario is positive within five years. The (22.5\% and $\$ 5)$ scenario is positive within four years. The $(10 \%$ and $\$ 15)$ and ( $35 \%$ and $\$ 5)$ scenarios are positive within three years. The (10\% and $\$ 24),(22.5 \%$ and $\$ 15),(22.5 \%$ and $\$ 10)$, and (35\% and 
$\$ 10)$ scenarios are positive within two years. Finally, the (35\% and $\$ 24),(22.5 \%$ and $\$ 24)$, and (35\% and $\$ 15)$ scenarios are all positive within one year. However, these scenarios do not include how income is split between landowners, landscapers, and retailers, which would affect final ROI time frames. Nevertheless, as many investments do not achieve a positive ROI within five years, these scenarios indicate that edible landscaping has significant ROI potential even considering conservative scenarios.

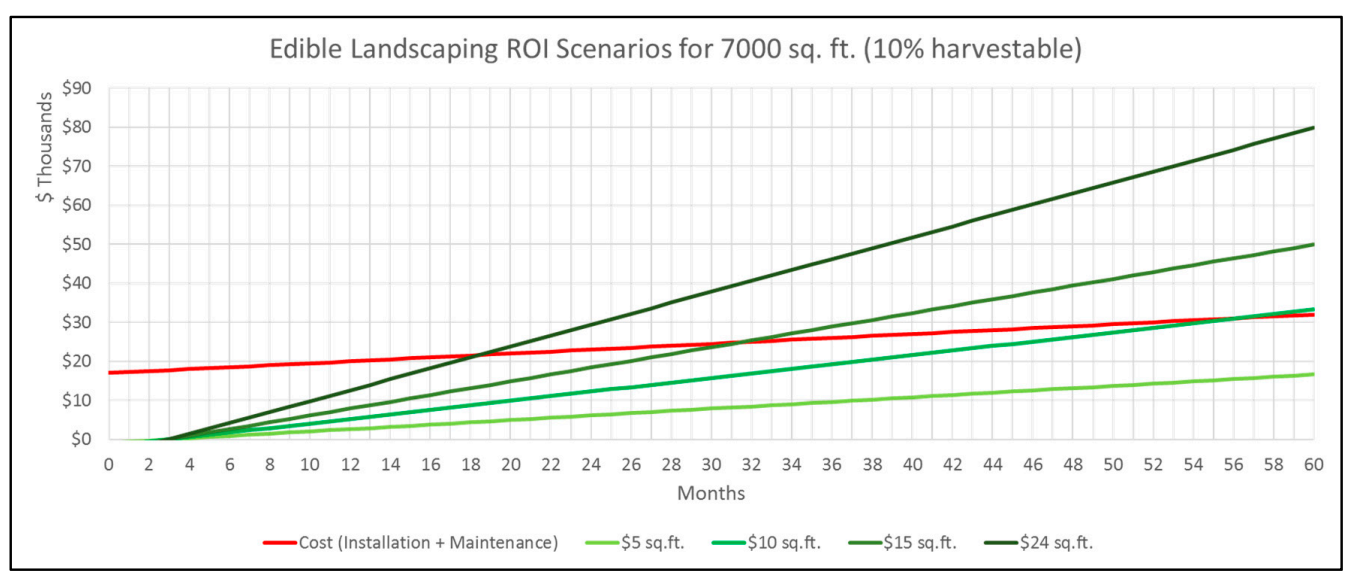

Figure 13. Edible landscaping ROI scenarios for 7000 sq. ft. (10\% harvestable).

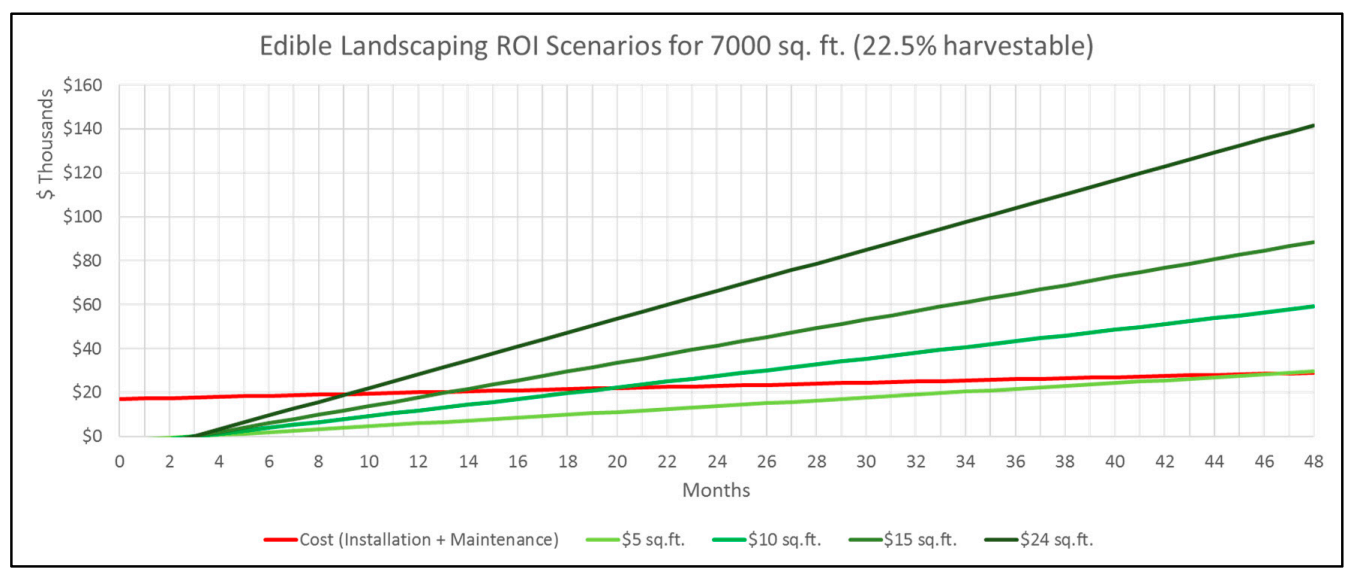

Figure 14. Edible landscaping ROI scenarios for 7000 sq. ft. (22.5\% harvestable).

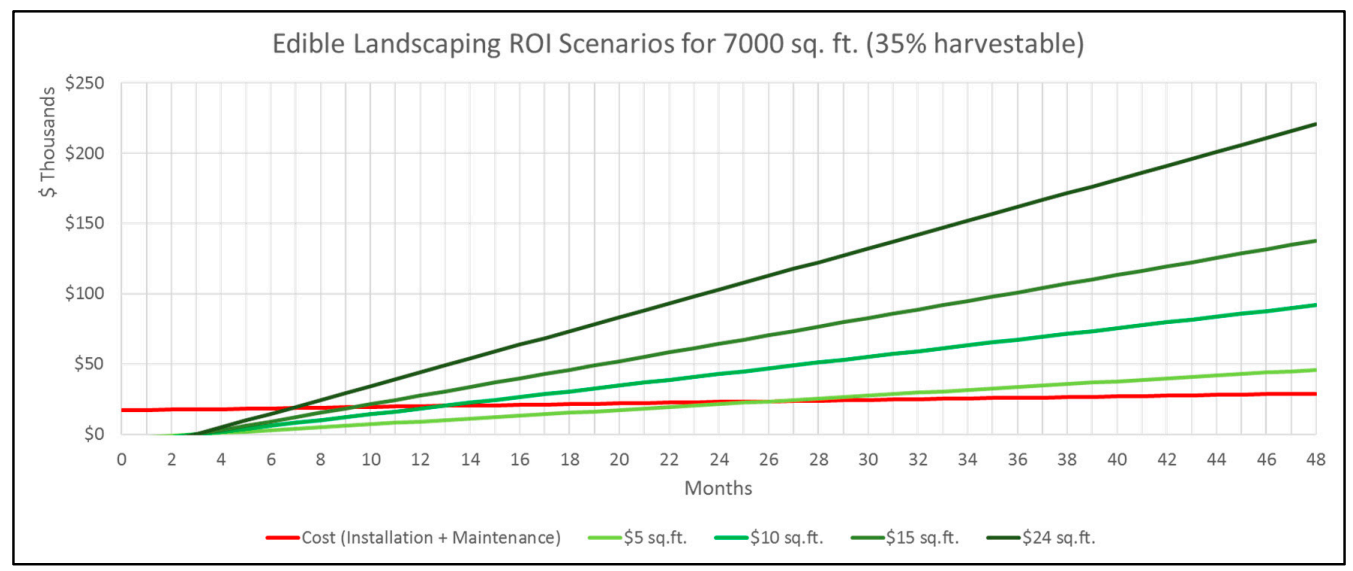

Figure 15. Edible landscaping ROI scenarios for 7000 sq. ft. ( $35 \%$ harvestable). 


\section{Discussion and Conclusions}

Our results indicate significant potential for edible landscaping in the Phoenix metro area. Key to this potential is the additional value from harvested products that implementation creates, which can be used to simultaneously incentivize and cover the costs of propagation. However, as with any system, there are many factors that could undermine this potential, as well as tradeoffs that need to be considered. Here we examine some potential sustainability implications if edible landscaping does become widely implemented, as well as explore future directions for multifunctional edible landscaping business models and research.

\subsection{Sustainability Implications of Edible Landscaping}

\subsubsection{Potential Impacts on the Landscaping Industry}

As edible landscaping directly supplants conventional landscaping, widespread adoption would have a profound effect on the landscaping industry as a whole, reducing market share available to conventional landscapers. However, our business model comparison indicates that conventional landscaping enterprises could transition to edible landscaping methods with relative ease, as the two models share many basic characteristics. The potential prerequisites for the transition from conventional to edible landscaping would be expanding employee training to include edible landscaping techniques, altering some purchasing decisions, and modifying value proposition messaging. In fact, shifting over to edible landscaping models could result in an overall healthier industry. Anecdotes from our interviewees and landscaping industry reports indicate that the current landscaping industry is quite vulnerable to economic downturns, due to elastic demand and low profit margins [21,36,37]. Landscape installation usually provides landscaping enterprises their highest profit margin, but is often considered a luxury, and thus demand sharply falls during recessions. Landscape maintenance is less elastic and therefore a more stable revenue source, but the market is very competitive with low profit margins. Since edible landscaping models have access to revenue streams and customer segments unavailable to conventional landscaping, they have greater potential to achieve higher profit margins and economic resilience. Another common issue brought up by landscaping enterprises is finding quality employees [36,37]. Our comparison suggests edible landscaping provides employees higher wages than the conventional type, which would increase the likelihood of attracting higher-quality employees. These points indicate edible landscaping could provide the landscaping industry a path to improve its economic resilience and sustainability. Nevertheless, just transitioning the existing landscaping industry to edible landscaping methods may not necessarily guarantee better urban sustainability outcomes. Current landscaping industry practices are already plagued with a wide variety of unsustainable behaviors (such as high usage of fertilizers and pesticides to maintain monoculture lawns, exploitative labor conditions dependent on migrant workers, water pollution and soil erosion from operations, etc.), spurred on by profit maximization and the lack of strong market regulation for landscaping practices in many US cities, and such behaviors could carry over to edible landscaping enterprises without accompanying regulation or other explicit preventative measures $[4,21,25,36,37]$. However, the authors do theorize that the diversified value chains and stakeholder relationships found in edible landscaping business models make them more likely to avoid these behaviors and produce more sustainable outcomes than conventional landscaping, but further research and observation would be needed to verify this.

\subsubsection{Resource Intensity of Edible Landscaping}

An important sustainability concern regarding edible urban landscaping is its resource intensity, as establishment and maintenance requires significant inputs of energy, water, materials, and labor. However, most edible landscaping is not proposed for virgin landscapes, but to replace conventional urban landscaping that will be or is already resource intensive. One research study examining the energy inputs/outputs of different landscapes found that edible landscaping did not require higher 
energy inputs than conventional ornamental landscaping, yet yielded significant energy outputs via produced edibles while the ornamental landscaping had no useful energy outputs [27]. This indicates that, in terms of energy efficiency, edible landscaping is superior to conventional landscaping as it creates more value from comparable energy inputs. But, in the desert climate of the Phoenix metro area water usage is of particular concern, and a legitimate critique against edible landscaping would be that it tends to require far more water than already widely used xeriscaping (low-water use landscaping), which could be problematic either in terms of increased water costs or reduced water conservation. However, barring a few exceptions, water rates in the Phoenix metro area are among the lowest in the US, with Phoenix residents averaging \$30.99 for 9000 gallons in 2014, and according to Enterprise B and Enterprise D, increased water costs were usually negligible when compared to other landscape maintenance costs [38,39]. As for water conservation concerns, these could be somewhat addressed, although not completely, by prioritizing low-water use edibles and precision irrigation. In fact, the Sonoran Desert surrounding the Phoenix metro area is home to many native edible plants that are desert-adapted. Once established these native species often require little to no irrigation, surviving on natural rainfall, along with some species being able to produce high value edibles, such as mesquite trees, which have been found to consistently produce enough seed pods annually for $5 \mathrm{lb}$. of mesquite flour commonly valued between $\$ 10-\$ 20$ per $1 b$. [40,41]. Nevertheless, increased water consumption would be a likely tradeoff for using edible landscaping, although in cases where edible landscaping would be replacing already water intensive but nonproductive landscaping such as grass turf, it would at least result in a better return on water investment or even lead to reduced water consumption depending on plant selection and irrigation design.

\subsubsection{Potential Impacts on Urban Environment and Activity}

The next area of consideration is how edible landscaping would interact with other urban environment aspects and various urban activities. There are several potential concerns that could preclude the use of edible landscaping on certain landscapes. For instance, sites often exposed to or already contaminated with high levels of pollution (industrial areas, heavily trafficked streets, storm water drainage basins, etc.), sites frequently disturbed by strong natural or man-made physical forces (floodplains, recreational fields, etc.), and sites that should not be disrupted in order to preserve inherent qualities (historic sites, nature preserves, etc.) [42]. However, with proper design, there are many urban environments and activities that could exist side by side with edible landscaping, and even if challenging landscapes were excluded, huge potential remains as they only represent a small share of the available area. Parks, while places of recreation activity, often have large sections receiving minimal use which could be managed by edible landscaping enterprises to produce edibles. Using native edible plants would avoid concerns of disrupting local biodiversity. Low traffic streets could support edible trees, while also providing shade for pedestrians. Edible landscaping could also have secondary benefits for the urban environment, such as reducing urban heat island (UHI) effects, reducing storm water runoff, and revitalizing the appearance of vacant lots [42]. Moreover, edible landscaping could encourage reduced application of toxic pesticides and herbicides on urban landscapes, as toxics tend to be avoided for the safety of caretakers and produced edibles, improving soil and water quality. In addition, even landscapes that are not compatible with edible landscaping could still be employed in a productive manner. For example, these landscapes could be used for pollinator gardens, to promote bee populations and support honey production, or plants that produce materials for textiles, dyes, perfumes, and other products [1]. However, another potential concern would be using public access spaces for edible landscaping, as conflicts of interest could arise if landscape production and harvesting is impeded by how the public utilizes the landscape; a likely example would be if members of the public foraged the edible landscaping products before they could be harvested and sold, thus reducing prospects for positive ROI. One way to manage such issues would be through ordinances restricting foraging, and in fact Phoenix, along with many other cities, currently prohibits any unauthorized harvesting of plants in parks; yet, such ordinances are difficult to enforce and therefore are often 
not actively enforced [43,44]. Common physical interventions to restrict access like fencing of the edible landscaping would also be undesirable due to potential concerns regarding financial costs and the pseudo-privatization of public land. However, other indirect methods could be used to deter foraging, such as selecting plant types that the general public would find unappealing or difficult to forage. An example of this would be the ASU Campus Harvest program, which annually obtains large harvests from its Seville orange trees and date palms, with little to no issues with unauthorized foraging, despite the campus grounds being public access and no fencing around the oranges or. The lack of foraging issues is likely due to the fact that Seville oranges are quite sour and dates being quite difficult to harvest, making them both unappealing to random foragers $[45,46]$. Still, even counting such measures, the nature of public access spaces inherently makes them more challenging to utilize for edible landscaping, and further consideration of potential consequences beyond what is discussed here would be needed.

\subsubsection{Potential Impacts on Food Markets and Local Urban Economy}

A consequence of widespread edible landscaping would be significant changes to the composition of local urban food systems and other resulting economic effects. The influx of new edible products would certainly change the supply and market dynamics of the local food system, although predicting the exact outcomes of such changes is challenging. There are many variables that could greatly influence outcomes, such as the type of edibles produced, and the channels used to introduce them into the food system. However, since food is an inelastic good, it is likely that edible landscaping products entering the local market would compete with and displace the sales of other local food products, reducing available market share for existing local producers and retailers as well as lowering market prices. Nonetheless, if measures were taken to smoothly integrate edible landscaping products into existing local supply channels or even larger regional or global food systems, then initial local market disruptions could be minimized. One integration avenue would be through food hubs, an emerging class of businesses that aggregate, market, and distribute local and regional food products to local, regional, or larger markets [47,48]. Food hubs could aggregate edible landscaping products with other local food products, and then sell the collective food hub products to larger markets, reducing direct competition between the edible landscaping and local food products at the local market level. However, the collective food hub products would instead compete with wholesale market products, in this regard, one study has shown that $\$ 1$ increase in demand for food hub products generates a $\$ 0.11$ reduction in wholesale product purchases [49]. Nonetheless, once edible landscaping products reach a large enough scale, then significant direct competition with local food products would probably be inevitable. Other likely economic effects would be increased local employment and spending as entrepreneur interviews indicated that edible landscaping tends to require more employee hours and local suppliers than conventional landscaping, along with improved household economic security and economic stimulus when the additional direct and indirect values created by edible landscaping enters households and the local economy. However, once the edible landscaping market reaches competitive maturity, profit maximization motives may bring about the similar systemic issues that produce unsustainable behaviors in many existing food systems and markets, such as monocultural practices, reliance on chemical inputs, market consolidation, low pricing trends which undermine livelihood outcomes, and community exploitation, requiring regulatory oversight or interventions $[25,50,51]$. On the other hand, the co-creative and community-based relationships encouraged by edible landscaping business models may serve to ameliorate these perverse tendencies by providing avenues for local community stakeholders to intervene and bring about more sustainable outcomes.

\subsubsection{Potential Impacts on Urban Communities and Social Groups}

Edible landscaping could also have considerable impacts on various urban communities and social groups. The landscaping industry tends to employ a large number of workers from certain social 
groups, such as temporary nonimmigrant workers and recent immigrants, who have difficulty getting jobs in other industries due to issues such as language barriers [36]. As much conventional landscaping work does not require significant prior experience or customer interaction, these social groups are able to perform well in these positions. However, our interviews indicate that edible landscaping tends to require more training and customer interaction than conventional landscaping, which would make it more difficult for these social groups to fill such positions. If the industry shifts over to edible landscaping models, then there might be fewer employment opportunities in landscaping for these social groups unless training was provided to them. However, edible landscaping also provides significant opportunities for other communities and social groups, specifically communities in food deserts and the food insecure. As these communities and groups have restricted access to fresh food, whether because of mobility or financial reasons, the presence of edible landscaping would provide them important nutritional access that they might not have otherwise.

\subsection{Future Directions for Multifunctional Edible Landscaping Business Models}

\subsubsection{HOA Subdivisions}

Our interviews revealed that a significant cost for landscaping enterprises was transportation. The costs associated with traveling back and forth from various landscaping sites, often with heavy equipment and materials, was a burden for all the enterprises we interviewed. Therefore, finding ways to minimize these costs would be helpful for model development. One way to do this would be for edible landscaping enterprises to approach communities with homeowner associations (HOA). These HOA communities often have large amounts of residential open space, usually managed by the HOA as common property, as well as shared community expectations or requirements regarding home landscaping. If edible landscaping companies were able to form partnerships with such communities, making sure their landscaping designs matched HOA requirements, they could then provide landscaping services for the communities' residential open space and any residents interested in receiving edible landscaping. The enterprises could even provide the residents discounted services to incentivize resident participation. The result of such partnership would be the minimization of enterprise transportation costs, as the landscapes they service would be close together within the HOA communities. This close clustering of serviced landscapes would also open up opportunities for synergistic design of the serviced landscapes, potentially increasing edible production. The HOA communities would, in turn, benefit by receiving lower landscaping costs and unifying images of being a "garden communities", perhaps even conducting activities such as neighborhood cookouts using community produced edibles.

\subsubsection{Municipal Parks and Urban Forestry Initiatives}

Edible landscaping enterprises could also partner with the largest urban land owners, municipal governments. Cities must devote considerable resources to managing the landscaping of municipal properties, including municipal parks and green space. However, cities often have limited capacities and budgets to manage their landscapes, resulting in them often contracting out landscaping services to minimize costs [52]. Edible landscaping enterprises could approach municipalities and offer to affordably service these properties. In exchange, the enterprise could convert underutilized sections of municipal properties into edible landscaping to generate revenue to cover landscaping costs. Another opportunity for partnership is through municipal urban forestry programs. Many cities, including several in the Phoenix metro area, have begun to develop formal urban forestry programs to increase their tree canopies and associated environmental benefits of urban trees [52]. However, a challenge for urban forests is ensuring the long-term survival of urban trees, as many trees do not receive sufficient care after being planted [53,54]. Edible landscaping enterprises could help with this issue by acting as the caretakers for any edible urban trees planted by urban forestry programs, which they would be allowed to harvest to cover their costs. But, as mentioned earlier, it is 
likely to be more challenging to achieve a positive ROI with edible landscaping on public access lands due to the risk that public use of the landscape may interfere with successful harvesting of landscape products. For such public-private partnerships to be successful, one or both partners may need to accept compromises to shoulder initial costs, with the hope that the long-term value for money or the non-financial benefits from the landscape (such as the public enjoying the edibles) will be worth the investment $[13,18,44]$.

\subsubsection{Low Income Communities}

Another opportunity area for edible landscaping companies is low income communities. Low income residents and landowners often cannot afford the luxury of maintaining a landscape, and as such have mostly been an inaccessible market for conventional landscaping. However, since the sale of harvested edible provides an additional revenue source, edible landscaping business models could successfully enter and operate in low-income markets. One way this could be achieved is enterprises could provide subsidized installation and maintenance fees in exchange for receiving a greater share of edible product sales income. This would relieve the financial burden of covering costs from low income area residents and land owners, while allowing edible landscaping enterprises to recoup their investment. Additionally, as low-income communities often suffer from the effects of unsafe, neglected landscapes and insufficient access to fresh food, implementation of edible landscaping could help them overcome these problems and improve their quality of life $[4,55]$.

\subsubsection{Edible Landscaping Enterprises as Community Investors Enabling Urban Development}

The scenarios that we conducted indicated that under the right conditions edible landscaping had the potential to achieve an impressive ROI. This quality opens the possibility for edible landscaping enterprises to become active community investors and enablers of urban development. If edible enterprises get to the point that they have sufficient reserve capital, they could begin to actively invest in reactivating vacant landscapes in neglected urban areas as edible landscaping, since their ROI would be sufficient to justify such investments. These efforts could then have secondary effects that could help the revitalization of these depressed urban areas. If these conditions do come to pass, then edible landscaping enterprises could become stimulators of urban development.

\subsection{Conclusions, Limitations, and Next Steps for Future Research}

For this study, we assessed if the value created by examined multifunctional edible landscaping business models provides a sufficient business case at enterprise and city scales to justify and incentivize widespread implementation. A business model comparison indicated that edible landscaping enterprises using multifunctional methods possess a greater range of value propositions and revenue streams than conventional landscaping enterprises, which enhances their competitive advantage. A GIS analysis determined that single family residential, residential open space, and municipal parks and schools are suitable landscapes for multifunctional edible landscaping, and that their total area in seven Phoenix metro area cities exceeded 180,000 acres. Scenarios using provided operational information found that the value creation for these edible landscapes could range between $\$ 3.9$ and $\$ 66$ billion, and that positive ROI could be achieved in 11 out of 12 scenarios within one to five years. While our study attempted comprehensiveness, our findings are insufficient for generalization and there are still many aspects needing further research. There are three research directions that we believe especially require attention. First, long-term evaluation of the socio-environmental sustainability outcomes of edible landscaping needs to be conducted. While our findings indicate that edible landscaping outcomes would likely be beneficial for urban areas and their residents, there still is not sufficient data to confirm such conclusions. Additionally, even if outcomes do turn out to be predominately beneficial and sustainable, critical assessment can still bring about significant improvements to edible landscaping models and methods. Second, regional variations of edible landscaping models, methods, and outcomes need to be examined. All the findings 
in this study are specific to the Phoenix metro area and our examined enterprises, and it is likely that conducting the same research with different enterprises or in different cities could result in drastically different findings. For example, the climate of the Phoenix metro area produces a very long growing season, which almost certainly influences ROI scenario results. Urban areas with shorter growing seasons are likely to have longer time frames for achieving positive ROI or may even be unable to achieve positive ROI. Also, many of the discussed factors are only applicable within domestic context of the United States, and either do not apply or would be significantly different in other countries. Third, in-depth examinations of other multifunctional urban landscape models and methods need to take place. This study primarily focused on edible landscaping, but there are other multifunctional landscape models that we did not examine, such as models revolving around ecosystem services, other forms of urban agriculture, energy production, and so forth. These other models also need research, as they may deliver valuable opportunities, perspectives, and insights that edible landscaping cannot provide. For instance, certain landscapes are not suitable for edible landscaping, but other multifunctional methods could work on these landscapes instead. If these other multifunctional models are not properly investigated, valuable solutions for urban sustainability challenges could be overlooked. If research and development of multifunctional landscaping models are conducted thoughtfully, it is the authors' opinion that multifunctional landscaping could bring about significant progress for sustainable urban transformation and improve the well-being of urban residents.

Acknowledgments: The authors greatly appreciate the enterprise owners and other professionals who provided their time and knowledge for interviews, as well as Jennifer Hodbod, who provided useful feedback and recommendations. The authors would also like to collectively thank the faculty and staff of the ASU School of Sustainability for their guidance and assistance.

Author Contributions: Christopher Robinson conceived the research idea and all authors contributed to research design and method selection; Christopher Robinson performed the interviews, data analysis, scenario calculations, and wrote the paper; Scott Cloutier and Hallie Eakin provided materials, information, and interview contacts, as well as contributed to reviewing and revising the paper.

Conflicts of Interest: The authors declare no conflict of interest.

\section{References}

1. Lovell, S.T.; Taylor, J.R. Supplying urban ecosystem services through multifunctional green infrastructure in the United States. Landsc. Ecol. 2013, 28, 1447-1463. [CrossRef]

2. Harris, E.M.; Polsky, C.; Larson, K.L.; Garvoille, R.; Martin, D.G.; Brumand, J.; Ogden, L. Heterogeneity in residential yard care: Evidence from Boston, Miami, and Phoenix. Hum. Ecol. 2012, 40, 735-749. [CrossRef]

3. Brandt, J.; Vejre, H.; Mander, U.; Antrop, M. Multifunctional Landscapes; WIT: Southhampton, UK, 2003.

4. Krishnaswami, R.J.; Merton, E. Neglected yards and community landscaping. Southeast. Geogr. 2015, 55, 225-251. [CrossRef]

5. Mander, U.; Wiggering, H.; Helming, K. Multifunctional Land Use: Meeting Future Demands for Landscape Goods and Services; Springer: Berlin/Heidelberg, Germany, 2007.

6. Tudor, A.T.; Ioja, I.C.; Rozylowicz, L.; Patru-Stupariu, I.; Hersperger, A.M. Similarities and differences in the assessment of land-use associations by local people and experts. Land Use Policy 2015, 49, 341-351. [CrossRef]

7. Fry, G.L.A. Multifunctional landscapes-Towards transdisciplinary research. Landsc. Urban Plan. 2001, 57, 159-168. [CrossRef]

8. Naveh, Z. Ten major premises for a holistic conception of multifunctional landscapes. Landsc. Urban Plan. 2001, 57, 269-284. [CrossRef]

9. Helming, K.; Wiggering, H. Sustainable Development of Multifunctional Landscapes; Springer: New York, NY, USA; Berlin, Germany, 2003.

10. Tress, G.; Tress, B.; Fry, G. Clarifying integrative research concepts in landscape ecology. Landsc. Ecol. 2005, 20, 479-493. [CrossRef]

11. Ferguson, J. Permaculture as Farming Practice and International Grassroots Network: A Multidisciplinary Study. Ph.D. Thesis, University of Illinois at Urbana-Champaign, Urbana, IL, USA, 2015. Available online: http:/ / hdl.handle.net/2142/89037 (accessed on 9 May 2017). 
12. O'Farrell, P.J.; Anderson, P.M. Sustainable multifunctional landscapes: A review to implementation. Curr. Opin. Environ. Sustain. 2010, 2, 59-65. [CrossRef]

13. Lovell, S.T. Multifunctional urban agriculture for sustainable land use planning in the United States. Sustainability 2010, 2, 2499-2522. [CrossRef]

14. Figge, F.; Hahn, T. Sustainable Value Added-Measuring corporate contributions to sustainability beyond eco-efficiency. Ecol. Econ. 2004, 48, 173-187. [CrossRef]

15. Kassem, E.; Trenz, O.; Hřebíček, J.; Faldík, O. Sustainability Assessment Using Sustainable Value Added. Procedia Soc. Behav. Sci. 2016, 220, 177-183. [CrossRef]

16. Sabol, A.; Sverer, F. A review of the economic value added literature and application. UTMS J. Econ. 2017, 8, 19-27.

17. Strakova, J. Sustainable value added as we do not know it. Bus. Theory Pract. 2015, 16, 168-173. [CrossRef]

18. Villani, E.; Greco, L.; Phillips, N. Understanding value creation in public-private partnerships: A comparative case study. J. Manag. Stud. 2017. [CrossRef]

19. Larsen, L.; Harlan, S.L. Desert dreamscapes: Residential landscape preference and behavior. Landsc. Urban Plan. 2006, 78, 85-100. [CrossRef]

20. Lawn \& Landscape. 2016 Top 100. Available online: https://www.lawnandlandscape.com/FileUploads / file/Lawn_Poster_List.pdf (accessed on 9 May 2017).

21. Rivera, E. IBISWorld Industry Report 56173: Landscaping Services in the US. Available online: https:/ / www.ibisworld.com/industry-trends / market-research-reports/administration-businesssupport-waste-management-services/administrative/landscaping-services.html (accessed on 9 May 2017).

22. Girotra, K.; Netessine, S. Business model innovation for sustainability. Manuf. Serv. Oper. Manag. 2013, 15, 537-544. [CrossRef]

23. Gorissen, L.; Manshoven, S.; Vrancken, K. Tailoring business model innovation towards grand challenges: Employment of a transition management approach for the social enterprise "re-use centers". J. Glob. Responsib. 2014, 5, 289-311. [CrossRef]

24. Koene, B.; Ansari, S. Institutional change and the multinational change agent: A study of the temporary staffing industry in Spain. J. Organ. Chang. Manag. 2011, 24, 511-531. [CrossRef]

25. Alexander, J. Environmental sustainability versus profit maximization: Overcoming systemic constraints on implementing normatively preferable alternatives. J. Bus. Ethics 2007, 76, 155-162. [CrossRef]

26. Alberti, F.G.; Varon Garrido, M.A. Can profit and sustainability goals co-exist? New business models for hybrid firms. J. Bus. Strategy 2017, 38, 3-13. [CrossRef]

27. Beck, T.B.; Quigley, M.F.; Martin, J.F. Emergy evaluation of food production in urban residential landscapes. Urban Ecosyst. 2001, 5, 187-207. [CrossRef]

28. Osterwalder, A.; Pigneur, Y.; Clark, T. Business Model Generation: A Handbook for Visionaries, Game Changers, and Challengers; John Wiley \& Sons: Hoboken, NJ, USA, 2010.

29. Arizona State University GIS Data Repository. Available online: https://lib.asu.edu/GIS/repository (accessed on 15 March 2016).

30. ESRI. World Imagery. Available online: https://www.arcgis.com/home/item.html?id= 10df2279f9684e4a9f6a7f08febac2a9 (accessed on 15 March 2016).

31. Algert, S.J.; Baameur, A.; Renvall, M.J. Vegetable output and cost savings of community gardens in San Jose, California. Res. Pract. Innov. 2014, 114, 1072-1076. [CrossRef] [PubMed]

32. Agrilyst. State of Indoor Farming September 2016. Available online: http:/ /www.dem.ri.gov/programs / agriculture/documents/stateofindoorfarming-report-2016.pdf (accessed on 15 November 2017).

33. Maki, O. How Urban Farmers Can Earn $\$ 75,000$ on 15,000 Square Feet. Civil Eats 2016. Available online: https: / civileats.com/2016/02/29/how-urban-farmers-curtis-stone-earns-75000-on-15000-square-feet/ (accessed on 15 November 2017).

34. Creasy, R.; Wilkinson Barash, C. Edible Landscaping: Grow $\$ 700$ of Food in 100 Square Feet. Mother Earth News 2010. Available online: https:/ / www.motherearthnews.com/organic-gardening/edible-landscapingzmaz09djzraw (accessed on 15 November 2017).

35. Cheap Vegetable Gardener. The Most Profitable Plants in Your Vegetable Garden. Available online: http:/ / www.cheapvegetablegardener.com/most-profitable-plants-in-your/ (accessed on 15 November 2017).

36. Lawn \& Landscape. 2015 State of the Industry Report. Available online: http:/ /www.lawnandlandscape. com/FileUploads / file/OctSOI_low-res.pdf (accessed on 15 March 2016). 
37. Lawn \& Landscape. 2016 State of the Industry Report. Available online: https:/ /www.lawnandlandscape. com/fileuploads/file/2016/11/SOI_PDF_2016.pdf (accessed on 9 May 2017).

38. Kuhney, J. Water Rates in Phoenix Metro Area. Arizona Republic 2014. Available online: http://www. azcentral.com/story/news/local/surprise/2014/04/16/water-rates-vary-phoenix-metro-area/7751735/ (accessed on 9 May 2017).

39. Swarner, J. Water Rates in Phoenix Among Lowest in Nation, Despite Rate Hike. Ariz. Repub. 2016. Available online: http:/ / www.azcentral.com/story/news/local/phoenix/2016/03/16/report-water-ratesphoenix-among-lowest-nation-despite-rate-hike/81878856/ (accessed on 9 May 2017).

40. Hodgson, W.C. Food Plants of the Sonoran Desert; University of Arizona Press: Tucson, AZ, USA, 2001.

41. Desert Harvesters. Time, Volume, \& Value of Harvesting \& Milling. Available online: http://www. desertharvesters.org/how-we-run-mesquite-millings/time-volume-value-of-pod-harvests / (accessed on 15 May 2017).

42. Angotti, T. Urban agriculture: Long-term strategy or impossible dream?: Lessons from Prospect Farm in Brooklyn, New York. Public Health 2015, 129, 336-341. [CrossRef] [PubMed]

43. Phoenix City Code, 24-37. Available online: http://www.codepublishing.com/AZ/Phoenix/?compiledPhoenix24/Phoenix24.html (accessed on 15 May 2017).

44. McLain, R.J.; Hurley, P.T.; Emery, M.R.; Poe, M.R. Gathering "wild" food in the city: Rethinking the role of foraging in urban ecosystem planning and management. Local Environ. 2014, 19, 220-240. [CrossRef]

45. Arizona State University Ground Services Arboretum. Edible Campus_Local Foods: Guide to Harvesting Produce at ASU. Available online: https: / / www.asu.edu/fm/documents/arboretum/CampusHarvest.pdf (accessed on 15 May 2017).

46. Wright, G.C. Date Cultivation in Arizona and the Bard Valley. J. Am. Pomol. Soc. 2012, 66, 110-117.

47. Berti, G.; Mulligan, C. Competitiveness of Small Farms and Innovative Food Supply Chains: The Role of Food Hubs in Creating Sustainable Regional and Local Food Systems. Sustainability 2016, 8, 616. [CrossRef]

48. Fischer, M.; Pirog, R.; Hamm, M.W. Food Hubs: Definitions, Expectations, and Realities. J. Hunger Environ. Nutr. 2015, 10, 92-99. [CrossRef]

49. Jablonski, B.B.R.; Schmit, T.M.; Kay, D. Assessing the Economic Impacts of Food Hubs on Regional Economies: A Framework that Includes Opportunity Cost. Agric. Res. Econ. Rev. 2016, 45, 143-172. [CrossRef]

50. Dixon, J. Diverse food economies, multivariant capitalism, and the community dynamic shaping contemporary food systems. Community Dev. J. 2011, 46, 20-35. [CrossRef]

51. Chase, L.; Grubinger, V. Food, Farms, and Community: Exploring Food Systems; University of New Hampshire Press: Durham, UK, 2014.

52. Richardson, B. (City of Tempe, Tempe, AZ, USA). Personal communication, 2016.

53. Hale, J.; Pugh, T.; Sadler, J.; Boyko, C.; Brown, J.; Caputo, S.; MacKenzie, A. Delivering a multi-functional and resilient urban forest. Sustainability 2015, 7, 4600-4624. [CrossRef]

54. Clark, K.H.; Nicholas, K.A. Introducing urban food forestry: A multifunctional approach to increase food security and provide ecosystem services. Landsc. Ecol. 2013, 28, 1649-1669. [CrossRef]

55. Vitiello, D.; Grisso, J.A.; Whiteside, K.L.; Fischman, R. From commodity surplus to food justice: Food banks and local agriculture in the United States. Agric. Hum. Values 2015, 32, 419-430. [CrossRef]

(C) 2017 by the authors. Licensee MDPI, Basel, Switzerland. This article is an open access article distributed under the terms and conditions of the Creative Commons Attribution (CC BY) license (http://creativecommons.org/licenses/by/4.0/). 